\title{
Bank Competition and Financial Stability: A Comparative Study of Mutual Savings Banks and Commercial Banks in Korea
}

\author{
Jin Q Jeon* \\ Kwang Kyu Lim**
}

The views expressed herein are those of the authors and do not necessarily reflect the official views of the Bank of Korea. When reporting or citing this paper, the authors' names should always be explicitly stated.

\footnotetext{
* Professor, Dongguk Business School, Dongguk University, Pil-dong 3-26, Jung-Gu, Seoul, 100-715, Republic of Korea, Email: jjeon@dongguk.edu

** Economist, Early Warning Team, Marcroprudential Analysis Department, the Bank of Korea, 39, Namdaemunno 3-Ga, Jung-Gu, Seoul, 100-794, Republic of Korea, Email: ikkyulim@bok.or.kr
}

The authors especially thank Tae Soo Kang, Byung Hee Sung, Jeong Eui Suh and Ju Yeon Lee at the Bank of Korea, and seminar participants at the financial stability forum of the Bank of Korea held in December 2012 for their helpful comments and suggestions on our original version. Jeon, professor at Dongguk University, acknowledges the financial support and hospitality of the Bank of Korea. All remaining errors are our own. 


\section{Contents}

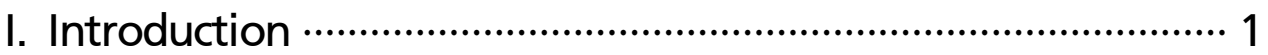

II. Literature Review …........................................................... 4

1. Estimation of competition ……...................................... 4

2. Bank competition and stability …………........................... 7

3. Mutual savings banks and commercial banks in Korea …............ 8

III. Sample and Methodology ………................................... 10

1. Sample

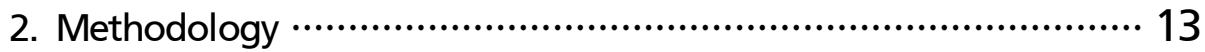

IV. Empirical Results …...................................................... 15

1. Analysis of market competition …………......................... 15

2. Competition and stability in the MSB industry …..................... 18

3. Competition and stability in the commercial bank industry $\cdots . . .22$

4. Additional analysis ….......................................................... 24

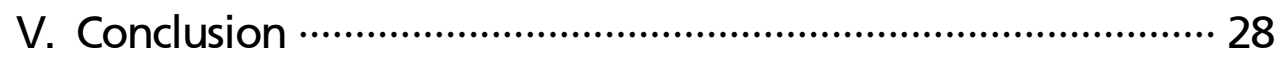

References …......................................................................... 31 


\section{Bank Competition and Financial Stability: A Comparative Study of Mutual Savings Banks and Commercial Banks in Korea}

This study examines the influence of competition and concentration on financial stability in the Korean financial industry. Specifically, we test two alternative hypotheses: the competition-fragility hypothesis versus competition-stability hypothesis by using the sample of two different types of banks - Korean commercial banks and mutual savings banks (MSBs). Using measures for the competitive level and financial stability such as the Boone Index and $Z$-score, we find that the relationship between competition and stability varies depending on the characteristics of financial institutions. In commercial banks as well as MSBs, however, our estimated Boone Indices suggest that competition was much higher before the recent global financial crisis, but after then it has gradually declined. As Boyd and De Nicolo (2005) suggest, competition has a positive effect on the stability of MSBs with greater business risk and weaker corporate governance. In reality, higher concentration and risk-shifting effects in a less competitive loan market have increased default risks of some MSBs since the recent crisis. Commercial banks, on the contrary, tend to be less stable when they face competition pressure while the relationship is nonlinear.

Keywords: Bank Competition, Risk-taking, Bank Stability, Risk Shifting

JEL Classification: G21, G23, L1 


\section{Introduction}

The literature provides two alternative hypotheses regarding the relationship between bank competition and its stability or risk-taking behavior. According to the conventional competition-fragility theory, the higher competition in the financial industry causes financial institutions to lose their market powers, leading to a decrease in their profitability. In order to recover from financial losses, financial institutions are more likely to invest in riskier portfolios. Consequently, this risk-taking behavior will undermine the stability of financial institutions (Keeley, 1990; Allen and Gale, 2000; Hellmann, Murdock, and Stiglitz, 2000, etc.).

Competition-stability theory, on the other hand, suggests that competition has a potentially positive effect on the stability of financial institutions. According to Boyd and De Nicolo (2005), banks with greater market share in the loan market which experience lower competition tend to impose higher interest rates on their loans. The greater interest burdens charged by banks in a less competitive market may increase the risk-taking behavior of borrowing firms. Boyd and De Nicolo consequently argue that since the risk is ultimately shifted from borrowers to banks, the default probability of banks increases in the riskiness of bank loans.

So far, however, empirical research has produced mixed results on the influence of bank competition on its stability. Tabak, Fazio, and Cajueiro (2012) who use bank data in Latin American banks support, in part, the competition-fragility theory, yet document the U-shaped relationship between competition and stability. They find that bank stability is improved at the high and low levels of competition while moderate competition significantly increases the risk of banks. On the other hand, Martinez-Miera and Repullo (2010) support the risk-shifting effect in the study of Boyd and De Nicolo (2005) in that greater interest rates in less competitive markets raise the risk of loans and thus make a bank bankruptcy more likely. They, however, additionally take into account the fact that greater interest rates also improve bank profitability, called the interest effect, and suggest the nonlinear relationship between competition and the risk of bank failure. We discuss the relevant literature in greater detail in section II-2.

The purpose of this paper is to investigate a relationship between competition and stability by using the sample of two different types of banks: mutual savings banks (MSBs, hereafter) and commercial banks. While previous studies provide theoretical and empirical links between bank competition and stability, there have been few studies 
investigating how such a relationship varies across the types of banks. This paper attempts to fill this gap in the conventional literature by examining whether differences in terms of governance structure, business models and regulatory treatments cause banks to interact with industry competition differently.

The primary difference in corporate governance between MSBs and commercial banks in the Korean markets is that MSB ownership is, in general, concentrated in the hands of a few individuals and a family's hand, while the ownership of commercial banks is widely dispersed.1) Also, since there are little mandatory requirements for disclosure compared to commercial banks, MSBs which provide little information on their financial situations are likely not to be affected by market discipline mechanisms. This creates moral hazard problems by major shareholders and senior management who are liable to take excessive risk in pursuit of private gains. Moreover, borrowers of MSBs are mainly small and medium-sized enterprises (SMEs, hereafter) possessing greater business and credit risks than those of commercial banks. Under this circumstance, MSBs in less competitive markets are more likely to be exposed to greater moral hazard and charge higher interest rates on their loans.2) As a result, with a lower level of competition, borrowers of MSBs are more likely to choose risky projects to repay their high interest rates, leading to a high possibility of defaults for both borrowers and MSBs. In the words of Martinez-Miera and Repullo, the risk-shifting effect may overwhelm the interest effect for MSBs.

This study investigates the hypothesis using quarterly panel data of MSBs and commercial banks from 1999, the end of Asian financial crisis, through 2011. We first estimate the level of bank competition. Since competition is hard to be directly measured, the literature provides several different methods to estimate the competitive level. We intend to follow Boone (2008) which measures competitiveness using operating efficiency, known as the Boone index. The conventional concentration ratio and Herfindahl-Hirschman Index are used as well as supplementary measures for bank competition, especially in the MSB case. We employ the $Z-$ score as a measure of bank

1) As of March 2011, the average ownership by the largest shareholders of large MSBs is $62.2 \%$ and that of small and medium-sized MSBs is 70.4\% (Korean Financial Supervisory Service, 2012).

2) It has been documented that the recent distresses of MSBs are mainly caused by excess risk-taking and, in some MSBs, unauthorized appropriation by major shareholders and senior management, and by the failure of effective monitoring through internal and external governance mechanisms (see the Korean Herald, May 2, 2011; Korea Times, May 14, 2012). 
stability which can capture how distant a certain bank is from its insolvency. Finally, we perform pooling regressions as well as panel analyses to examine the relationship between competitive levels and the stability of MSBs and commercial banks. Section III describes our measures and methodology in more details.

Our empirical results generally support the hypothesis that the effect of bank competition on its stability is different depending on the characteristics of financial institutions. The results of our multiple regressions show that competition has a significant and positive effect on the stability of MSBs with weak corporate governance. On the contrary, competition pressure significantly reduces the stability of commercial banks but, consistent with Tabak, Fazio, and Cajueiro (2012), the relationship turns out to be nonlinear. The results are robust across alternative proxies for competition and stability as well as various model specifications. Therefore, we conclude that for commercial banks higher competition creates the trade-off between the risk-shifting effect and interest effect, but the risk shifting effect overwhelms the interest effect for MSBs when the market is less competitive.

This paper contributes in several ways. To our knowledge, our research is among the first to provide comprehensive evidence on the relationship between bank competition and stability, conditional on different bank characteristics. The paper furthers our understanding of the influence of bank competition on its stability by showing that competition significantly decreases risk-taking behaviors of MSBs with weaker corporate governance and greater business risk, while it has a nonlinear relationship for commercial banks. Moreover, it is the first paper to analyze Korean MSBs by using hand-collected data. So far, there is no published empirical research examining MSBs due to the lack of available data because most of them are non-listed.3) Finally, while the previous literature uses annual financial data in its analysis, we intend to provide more reliable results from our empirical tests by using quarterly financial data, which enables us to analyze a larger number of observations. We should, however, be clear about the limitation of our paper. Due to the lack of detailed information on corporate governance of MSBs, the paper does not address how the corporate governance mechanism of banks affects the relationship between competition and stability, which we leave for the future research.

3) As of year 2011, only 7 out of 105 MSBs were listed in the Korean exchange. But, only one bank, Pureun savings bank is listed in 2013 due to the continuing delisting of other listed MSBs. 
The paper is organized as follows. Section II is the literature review of related area. In Section III, we describe our sample and empirical methodology. Section IV analyzes the relationship between competition and stability, while Section V concludes.

\section{Literature Review}

\section{Estimation of competition}

An increasing number of studies attempt to estimate a competitiveness level in the banking industry. Given that competition cannot be measured directly, a number of indirect measurement techniques have been developed, largely divided into the structure-conduct-performance $(S C P)$ and competition-contestability approaches. The structural methods to assess the competitive level in the banking industry are based on the $S C P$ assumption which predicts that the number of banks and their market shares determine the competitive behavior of financial institutions. According to this approach, the greater market concentration decreases the competitive level. The conventionally and frequently used measures include the concentration ratio $(C R$, hereafter) and Herfindahl-Hirschman Index (HHI, hereafter). $C R_{N}$ which is defined as the market share held by top $N$ banks and $H H I$ which is calculated by squaring the market shares of all $K$ banks and summing the squares are as follows.

$$
C R_{N}=\sum_{i=1}^{N} \text { Market }_{-} \text {Share }_{i}, H H I=\sum_{i=1}^{K}\left(\text { Market }_{-} \text {Share }_{i}\right)^{2}
$$

The U.S. Department of Justice and FTC (Federal Trade Commission) consider a market with less than 1,500 to be a competitive market place, 1,500 2,500 to be a moderately concentrated market place, and 2,500 or higher to be a highly concentrated market place. ${ }^{4)}$

Contrary to the SCP paradigm, the non-structural approach based on the

4) The market is perfectly competitive if $H H I$ is 100. See "Horizontal Merger Guidelines" (Aug. 19, 2010, U.S. Department of Justice and FTC). 
competition-contestability theory does not assume, a priori, that concentrated markets are less competitive. It suggests that, in the absence of entry barrier, the markets where a small number of firms serve can be nevertheless characterized by competitive equilibrium because of potential short-term entrants (Baumol, 1982; Baumol, Panzar, and Willig, 1982; among others). This non-structural approach directly measures bank competitiveness without considering the type of market structure.

Panzar and Rosse $(1982,1987)$ estimate the competitive behavior of banks based on the comparative static properties of a cross-sectional revenue equation. According to Panzar and Rosse, the elasticity of a bank's revenue to its input factors is estimated to construct a pivot statistics, called ' $H$ statistics', to test whether the market is monopolistic or competitive. The $H$ statistics is obtained from the following equation.

$$
H=\sum_{i=1}^{I}\left(\delta R^{*} / \delta \omega_{i}\right) \times\left(\omega_{i} / R^{*}\right)
$$

Where $\omega_{i}$ is the price of input $i$ and $R$ represents the total revenue. The marginal revenue function is assumed to have a log-linear form as follows.

$$
\ln R_{i t}=\alpha+\beta_{1} \ln W_{i t}+\beta_{2} \ln F_{i t}+\beta_{3} \ln R_{i t}+\sum_{k=1}^{K} \theta_{k} \chi_{k i t}+e_{i t}
$$

Where $W, F$, and $R$ are the prices of three input factors; labor, physical capital, and human capital, and $\chi$ denotes firm-specific control factors.

$H$ is defined by the sum of input price elasticity $\left(\beta_{1}, \beta_{2}, \beta_{3}\right)$ and reflects the competitive structure of the market. Panzar and Rosse prove that the negative $H$ represents a classical monopolist or collusive oligopolist, $H$ between 0 and 1 represents a monopolistic competitor, and a unit $H$ represents a competitive price-taker. While Panzar and Rosse's $H$ statistics has been widely employed in the empirical literature (Claessens and Laeven, 2004; De Bandt and Davis, 2000; among others), Bikker and Haaf (2002) and Bikker, Shaffer, and Spierdijk (2012) point out that the competitive level based on the $H$ is systematically overestimated and that the tests on both monopoly and perfect competition are biased, due to the use of revenues over total assets as a dependent variable instead of un-scaled bank revenues. Moreover, since the model, by its definition, estimates an $H$-statistics for the whole sample period, it is inappropriate 
for researchers who attempt to measure the competition structure on the annual or quarterly basis.

Boone (2008) estimates the level of bank competition by investigating the relationship between bank performance and efficiency measured as marginal costs. According to Boone, when the market becomes more competitive, efficient firms are rewarded more and inefficient firms are punished more harshly than they are in the less competitive market. Hence, Boone calculates the competitive levels by estimating the elasticity of a firm's performance, in terms of market shares, with respect to its marginal costs as follows.

$$
\ln \left(M S_{i t}\right)=\hat{\alpha}+\hat{\beta} \ln \left(M C_{i t}\right)
$$

$M S$ denotes the market shares in the loans or total assets of bank $i$ and $M C$ is the marginal costs. The estimated coefficient $\beta$ is interpreted as the profit elasticity, called Boone index, which is negative, i.e. banks with greater marginal costs lose market shares. Since competition enhances this negative relationship, the greater is the bank competition, the more negative is the Boone index.

Since marginal costs are not directly observed, empirical studies approximate them by calculating average variable costs (Schaeck and Cihak, 2010) or by using a translog cost function (Leuvensteijin, Bikker, Rixtel, and Sorensen, 2011). In our paper, we follow Leuvensteijin et al. and estimate the following cost function.

$$
\begin{aligned}
\ln \left(C / \omega_{3}\right)= & \delta_{0}+\sum_{j} \delta_{j} \ln y_{j}+\sum_{j} \sum_{k} \mu_{j k} \ln y_{j} \ln y_{k}+\sum_{k} \beta_{k} \ln \left(\omega_{k} / \omega_{3}\right) \\
& +\sum_{j} \sum_{k} \gamma_{j k} \ln y_{j} \ln \left(\omega_{k} / \omega_{3}\right)+\sum_{j} \sum_{k} \theta_{j k} \ln \left(\omega_{j} / \omega_{3}\right) \ln \left(\omega_{k} / \omega_{3}\right)+e
\end{aligned}
$$

Where $C$ is bank operating expenses, $y$ is outputs including total loans $\left(y_{1}\right)$, total securities $\left(y_{2}\right)$, and non-interest income $\left(y_{3}\right)$. The $\omega$ represents inputs including the prices or costs of labor $\left(\omega_{1}\right)$, of funding capital $\left(\omega_{2}\right)$, and of physical capital $\left(\omega_{3}\right)$. For convenience, the above function omits bank $i$ and time $t$. By taking the first derivative of the translog cost function with respect to total loans, we obtain the marginal costs of loans as follows. 


$$
M C_{1}=\frac{\partial\left(\frac{c}{\omega_{3}}\right)}{\partial y_{1}}=\frac{\left(\frac{c}{\omega_{3}}\right)}{y_{1}} \frac{\partial \ln \left(\frac{c}{\omega_{3}}\right)}{\partial \ln y_{1}}
$$

\section{Bank competition and stability}

Theoretical models and empirical results on the relationship between bank competition and stability provide conflicting evidence. According to the competitionfragility view, a greater competitive level in the banking industry leads to more fragility. On the other hand, since banks have the numerous lending opportunities and increase profits and capital ratios in a less competitive market, they can withstand any economic shocks and are less likely to take excessive risk. Keeley (1990) developed a theoretical model which predicts that banks with more pressures on their profits have higher incentives to take more excessive risk which results in a greater probability of their defaults. Allen and Gale (2000) reported that the number of competitors in the loan markets has a positive effect of bank defaults. Hellmann, Murdock, and Stiglitz (2000) examined the relationship between competition for deposits, risk taking and regulation in a dynamic framework. They argue that the removal of interest ceilings on deposits erodes franchise value and motivates moral hazard behavior by banks. The framework of these models is characterized by the fact that bank competition is modeled on the liability side and asset allocation decisions are modeled on the asset side which is not affected by bank competition.

Recent papers, on the other hand, take into account the relationship between banks and borrowers on the asset side of banks. Boyd and De Nicolo (2005), in their theoretical model, assume that borrowing firms entirely determine the risk of projects in the condition of the loan rates set by banks. The paper supports the competition-stability hypothesis by showing that greater concentration (less competition) causes banks to become riskier because the higher loan rate charged by banks with less competition implies the greater bankruptcy risk for borrowing firms. The empirical study by Boyd, De Nicolo, and Jalal (2006) who measure market structure by concentration indicators shows that, consistent with Boyd and De Nicolo (2005), the probability of bank failure increases in the level of concentration in the bank industry. Martinez-Miera and Repullo (2010) point out that the competition-stability view supported by Boyd and De Nicolo 
does not necessarily hold when the loan defaults are imperfectly correlated. On one hand, greater competition decreases the risk taking by borrowing firms and thus reduces the probability of bank defaults, called the risk-shifting effect. On the other hand, however, a decrease in loan rates due to greater competition reduces bank profits, called the margin effect, which is not considered in Boyd and De Nicolo. As a result, Martinez-Miera et al. suggest a nonlinear U-shaped relationship between competition and bank risk taking.

Recent empirical literature on the effect of bank competition on its stability provides mixed results. Berger, Klapper, and Turk-Ariss (2009) examine 8,235 banks in 23 developed economies and report the results that support both the competition-fragility and competition-stability view. Specifically, they find that banks with greater market power have riskier loan portfolios but the risk is traded off by higher capital ratios or other risk-mitigating techniques. Tabak, Fazio, and Cajueiro (2012) use bank data in 10 Latin American countries from 2003 to 2008 and find evidence that the relationship between competition and risk-taking is nonlinear. That is, both high and low levels of competition significantly increase bank stability, while the opposite is true for moderate competition. Beck, De Jonghe, and Schepens (2012) study a cross-country variation in the relationship between bank competition and stability, investigating how heterogeneous regulatory and institutional features affect this relationship across countries. The paper shows that competition significantly decreases bank stability in countries with stronger activity restrictions and more homogenous market environments. They also find that the deposit insurance policy and efficiency of credit information sharing are the important determinants. Finally, Liu and Wilson (2011) examine whether the effect of competition on stability varies depending on the characteristics of banks in the Japanese market. They find that competition enhances the stability of banks with lower stability level, but damages the stability of banks with higher stability levels.

\section{Mutual savings banks and commercial banks in Korea}

An MSB based on Mutual Savings Banks Act in 2001 is one of the non-bank depositary institutions. It is introduced by the Korean government in order to protect costumers by incorporating private lenders in to the financial landscape and rationalizing their business, as well as extending financial intermediary for SMEs which 
have low credit ratings and sound solvency. MSBs charge higher interest rates than commercial banks to expand their business base and to compensate for greater perceived risk. Due to drastic deregulations by the Korean government in order to support microfinance and promote small loan markets, and enlarge financial inclusion, MSBs aggressively expanded microcredit loans during the mid-2000s. Furthermore, they enjoyed the boom as real estate project financing (PF) loans increased steeply owing to the housing market boom. Entering into 2010, the sluggishness in real estate business and global financial crises increased defaults in real estate PF loans extended by MSBs. Consequently, as of end-2011, MSBs have greater risk and more vulnerable loans than other financial institutions. For example, low-rated loans whose borrower's credit score is recorded at 7 and over occupy half of their total household loans, according to the Bank of Korea.5) Average credit rating of companies borrowing from MSBs is CC-rated. The proportion of loans whose credit rating is B-rated and above, in general considered relatively good, is only $20 \%$ of total corporate loans. It has been documented that the distresses of MSBs are mainly caused by their excessive risk-taking attitudes and, in some MSBs, by the unauthorized appropriation by major shareholders and senior management, and by the failure of effective monitoring through internal and external governance mechanisms.

According to the Korea Federation of Saving Banks (KFSB), the number of MSBs showed a downward trend from 211 in end-1998 to 105 in end-2010. During this period, many MSBs are restructured by license revocations, mergers and acquisitions, and purchase and assumptions (P\&A). Furthermore, about 20 banks (for example, Samhwa, Busan, etc.) were ordered to suspend business between 2011 and 2012. As a result, 93 MSBs are in business as of end-June 2012. Default problems of MSBs are not yet solved in Korea because there are worries about additional defaults in real estate PF loans and uncertainties throughout the industry caused by a series of business suspensions of some large-sized MSBs. The KFSB reports that the asset size of MSBs expanded from 25 trillion won in end-2002 to 87 trillion won at its peak in end-2010. After then, however, their total asset size has diminished very sharply, approximately 60 trillion won as of end-2011.

5) In Korea, a borrower's credit score by financial institutions ranges from 1 to 10 . Higher credit score means weaker status of one's repayment capacity. Accordingly, borrowers with credit score 7 and over have a higher possibility of delinquency than those with low credit score. 
Korean commercial banks experienced a strong restructuring after or as long as its government put a large scale of public funds to insolvent banks from 1997 to 1998, when Korea suffered from a currency crisis. Entering the 2000s, Korean commercial banks also continued to be larger and larger through mergers. In 2001, Korean megabanks started from Woori-bank that was merged into by Peace bank of Korea and Hanvit-bank, followed by Kookmin-bank (merged bank with Housing \& Commercial bank) and Shinhan-bank (merged bank with Cho Hung bank). City-bank Korea took KorAm bank over in 2004 and First city bank of Korea was acquired by a British-based bank, Standard Chartered Plc in April 2005. As a result of a series of restructurings in the Korean banking system since the Asian currency crisis, the number of commercial banks (including regional banks) declined from 26 banks in 1997 through 17 banks in 2000, to 13 banks as of 2012. Meanwhile, including five specialized banks, the number of domestic banks is 18 banks. Korean banking industry has experienced a large-scale restructuring during the short period. Consequently, this has led to the rise in degree of concentration within our banking industry and concerns have ceaselessly been raised over a marked decline in market competition.

\section{Sample and Methodology}

\section{Sample}

The sample period starts on January 1999 and ends on December 2011 for commercial banks. For MSBs, however, it starts from 2003 due to data limitation. We obtain financial data of domestic banks (including regional and specialized banks) and hand-collect the data of MSBs, most of which are non-listed firms. For domestic banks, we exclude Korea Exim bank whose management style is different from other commercial banks. For example, the bank does not extend household loans. The database that we use includes the Data Analysis, Retrieval and Transfer System (DART) and Financial Statistics Information System (FISIS) maintained by the Korean Financial Supervisory Service (FSS), and the Economic Statistics System (ECOS) by the Bank of Korea. Since the data from the DART and ECOS is not sufficient for our analyses, we collect the data based on the report of each MSB. Even though most of empirical studies 


\section{$11 \quad$ BOK Working Paper No.2013-18 (2013.7)}

on the banking competition use the annual financial data, we use the quarterly data, which enables us to provide more reliable results.

Table 1 reports the descriptive statistics for our sample of MSBs and commercial banks (Panel A \& B). Their market shares are calculated based on total assets, total loans, household loans, and commercial loans. The average market share in total assets is $8.489 \%$ for MSBs and $5.882 \%$ for commercial banks. The size of commercial banks is greater than that of MSBs. The natural logarithm of total assets for MSBs is, on average, 7.652, while it is $\mathbf{1 7 . 4 0 4}$ for commercial banks. The average profit ratio, net income divided by total revenues, of MSBs is $-5.599 \%$, which reflects the depression in the MSB industry since the late 2000s as described in Section II-3. The greater standard deviation of profit ratios for MSBs compared to commercial banks suggests that MSBs are less stable than commercial banks. The loan to deposit ratio and commercial loan to home loan ratio for MSBs are, on average, $83.095 \%$ and 8.221 times, respectively, while those for commercial banks are $113.466 \%$ and 2.259 times, respectively. The average BIS ratio defined as the ratio of the capital to the risk-adjusted assets is $10.851 \%$ for MSBs and $11.862 \%$ for commercial banks. In addition, the variable descriptions of our sample are briefly suggested in the same Table 1 .

Table 1: Descriptive statistics

Panel A. MSBs

\begin{tabular}{|c|c|c|c|c|}
\hline \multicolumn{2}{|c|}{$N$} & Mean & Median & Stdev. \\
\hline Market Share (\%) of & \multicolumn{3}{|c}{} \\
\hline Total Assets & 5,890 & 8.489 & 4.743 & 9.991 \\
\hline Total loans & 3,456 & 0.955 & 0.489 & 1.481 \\
\hline Household loans & 3,456 & 0.955 & 0.541 & 1.600 \\
\hline Commercial loans & 3,456 & 4.557 & 2.062 & 6.586 \\
\hline Ln(Assets) & 5,890 & 7.652 & 7.524 & 1.089 \\
\hline Profit ratio (\%) & 3,432 & -5.599 & 4.632 & 76.620 \\
\hline Loan to Deposit (\%) & 5,888 & 83.095 & 84.623 & 19.487 \\
\hline Commercial to Home loan (x) & 3,456 & 8.221 & 3.564 & 14.635 \\
\hline BIS (\%) & 3,117 & 10.851 & 9.820 & 16.615 \\
\hline
\end{tabular}


Panel B. Commercial banks

\begin{tabular}{|c|r|r|r|r}
\multicolumn{2}{|c|}{} & N & Mean & Median \\
Market Share (\%) of & \multicolumn{3}{|c}{ Stdev. } \\
\hline Total Assets & 884 & 5.882 & 4.300 & 5.110 \\
\hline Total loans & 880 & 5.909 & 3.416 & 5.887 \\
\hline Household loans & 874 & 5.950 & 2.545 & 8.360 \\
\hline Commercial loans & 880 & 8.156 & 4.945 & 7.934 \\
\hline Ln(Assets) & 884 & 17.404 & 17.723 & 1.322 \\
\hline Profit ratio (\%) & 820 & 3.225 & 4.213 & 13.923 \\
\hline Loan to Deposit (\%) & 833 & 113.466 & 97.737 & 57.881 \\
\hline Commercial to Home loan $(x)$ & 874 & 2.259 & 1.973 & 1.876 \\
\hline BIS (\%) & 866 & 11.862 & 11.655 & 3.868 \\
\hline
\end{tabular}

Notes: The sample period starts on January 1999 for commercial banks and on January 2003 for MSBs due to data limitation and ends on December 2011. We obtain financial data of domestic commercial banks (including regional and specialized banks) and hand-collect the data of MSBs, most of which are non-listed banks, from the Data Analysis, Retrieval and Transfer System (DART) and Financial Statistics Information System (FISIS) maintained by the Korean Financial Supervisory Service (FSS), Economic Statistics System (ECOS) by the Bank of Korea, and the quarterly reports of MSBs. Market share is calculated in terms of total assets, total loans, household loans, and commercial loans.

Variable descriptions

\begin{tabular}{l|l}
\hline \multicolumn{1}{c|}{ Name } & \multicolumn{1}{c}{ Descriptions } \\
\hline Ln(Z) & Natural logarithm of the $Z-$ score, described in Section III-2 \\
\hline Competition & $\begin{array}{l}\text { A dummy which takes a value of } 1 \text { if Boone index is significantly } \\
\text { negative, i.e. if competitive pressure exists, and 0, otherwise }\end{array}$ \\
\hline Inverse of Boone Index & The opposite of Boone index, described in Section III-2 \\
\hline Inverse of Boone Index ${ }^{2}$ & Squared inverse of Boone index \\
\hline Ln(Assets) & Natural logarithm of total assets of banks \\
\hline Profit ratio & Total net income to total revenues ratio \\
\hline Foreign & A dummy equal to 1 for a foreign bank and 0, otherwise \\
\hline Loan to Deposit & Total loans to total deposits ratio \\
\hline Loan to Deposit ${ }^{2}$ & Squared Loan to Deposit \\
\hline Commercial to Home loan & Commercial loans (corporate lending) to household loans ratio \\
\hline CD Volatility & Monthly volatility of CD rates for prior one year \\
\hline
\end{tabular}




\section{Methodology}

We estimate the following regression models in order to examine the effect of bank competition on stability.

$$
\text { Stability }_{i t}=\alpha+\beta \text { Comperition }_{t}+\sum_{k} \gamma_{k} X_{k i t}+v_{i t}
$$

Our measures for Stability and Competition are discussed in more details below. $X$ is a set of control variables including bank-specific and market-related variables. We conduct both OLS and panel analyses to estimate the equations.

Following Laeven and Levine (2009), Boyd, De Nicolo, and Jalal (2006) and many others, we use the $Z$ - score as a measure of bank stability. The $Z-$ score is defined as the sum of the ROAs and capital ratios divided by the standard deviation of ROAs.

$$
Z-\text { score }=(\text { ROA }+ \text { Capital Ratio }) / \sigma_{\text {ROA }}
$$

We calculate the $Z-$ score by using the ROAs for prior 4 quarters as well as prior 8 quarters. The $Z$-score which measures how distant a bank from insolvency is inversely proportional to the probability of bank defaults. That is, the greater $Z-$ score represents a lower bankruptcy risk.

Our key measure of bank competition is the Boone index discussed in Section II-1. More specifically, we estimate the Boone index for the entire sample period as well as for the specific quarter.

$$
\begin{aligned}
\ln \left(M S_{i t}\right)= & \hat{\alpha}+\hat{\beta} \ln \left(M C_{i t}\right)+e_{i t} \\
\ln \left(M S_{i t}\right)= & \alpha+\sum_{t=1999 \mathrm{Q} 1}^{2011 \mathrm{Q} 4} \beta_{t} \ln \left(M C_{i t}\right) * \text { QuarterDummy } \\
& +\delta_{t} \text { QuarterDummy } y_{t}+\varepsilon_{i t}
\end{aligned}
$$

In the first regression, the Boone index for the period of 1999-2011 is obtained. In the second regression, we interact the Boone index with quarterly time dummies and control for the quarter effect. The estimation of the Boone index for each quarter is a 
result of this specification. The market share is mainly based on total assets and total loans, but also calculated with respect to total household loans and commercial loans. The negative Boone index suggests that an increase in marginal costs decreases market shares and thus competitive pressure does in fact exist in the banking financial industry. In order to make it directly proportional to the level of competition, we employ the opposite of the Boone index (Tabak, Fazio, and Cajueiro, 2012). We also use a dummy which takes a value of 1 for the significantly negative Boone index and 0, otherwise, as a proxy for competition.

The conventional measures for market concentration such as $C R$ and $H H I$, described in Section II-1, are also employed as supplementary measures for competition. $C R$ is defined as the sum of market shares of the $N$ largest banks in the market, while $H H I$ is calculated by squaring the market share of each bank and then summing the squares.

$$
C R_{N}=\sum_{i=1}^{N} \text { Market }_{-} \text {Share }_{i}, H H I=\sum_{i=1}^{K}\left(\text { Market }_{-} \text {Share }_{i}\right)^{2}
$$

Although there is no rule for the determination of the number of $N, C R_{4}$ and $C R_{8}$ are most frequently used. Based on the previous literature, we include the bank size ( $L n$ (Assets)), profitability (Profit ratio), loan-deposit ratio (Loan to Deposit), and commercialhousehold loan ratio (Commercial to Home loan) as control variables in our regression models. We also include the fluctuation of $C D$ rates ( $C D$ Volatility) in order to control for the effect of market situations. Additionally, the variable controls for the effect of business and financial cycles. We think that it is a better choice than the variable of GDP because the volatility of interest rates generally reflects both real economy and financial situations. Furthermore, if both of them employed, multicollinearity may affect our regressions. Also, banking industry tends to be more influenced by interest rates. Notably, most lending interest rates are linked to $\mathrm{CD}$ rates. 


\section{Empirical Results}

\section{Analysis of market competition}

Table 2 presents the results of Boone indices for both Korean commercial banks and MSBs estimated for the entire sample period (1999 2011).

Table 2: Boone index for the whole period

\begin{tabular}{|c|c|c|c|c|c|c|}
\hline & \multicolumn{3}{|c|}{ MSBS } & \multicolumn{3}{|c|}{ Commercial Banks } \\
\hline & Coef. & $t$ & $P>|t|$ & Coef. & $t$ & $P>|t|$ \\
\hline \multicolumn{7}{|c|}{ Panel A. Dependent variable : $L n(M S)$ in total assets } \\
\hline $\operatorname{Ln}(M C)$ & -0.581 & -7.20 & $0.000^{* * *}$ & -0.348 & -7.25 & $0.000^{* * *}$ \\
\hline Intercept & 0.010 & 0.16 & 0.869 & 2.080 & 16.99 & $0.000^{* * *}$ \\
\hline No. of Obs. & 1970 & & & 860 & & \\
\hline F tests & 51.82 & & & 52.54 & & \\
\hline$R^{2}$ & 0.033 & & & 0.064 & & \\
\hline
\end{tabular}

Panel B. Dependent variable : $\operatorname{Ln}(M S)$ in total loans

\begin{tabular}{l|r|r|r|r|r|r}
\hline$L n(M C)$ & -0.913 & -10.57 & $0.000^{* * *}$ & -0.432 & -9.76 & $0.000^{* * *}$ \\
\hline Intercept & -4.377 & -64.35 & $0.000^{* * *}$ & -2.341 & -19.87 & $0.000^{* * *}$ \\
\hline No. of Obs. & 1777 & & & 860 & & \\
\hline F tests & 111.78 & & & 95.18 & & \\
\hline$R^{2}$ & 0.073 & & & 0.104 & & \\
\hline
\end{tabular}

Panel C. Dependent variable : $L n(M S)$ in total commercial loans for MSBs and total household loans for commercial banks

\begin{tabular}{l|r|r|r|r|r|r}
\hline $\operatorname{Ln}(M C)$ & -1.023 & -9.36 & $0.000^{* * *}$ & -1.005 & -12.06 & $0.000^{* * *}$ \\
\hline Intercept & -3.144 & -36.01 & $0.000^{* * *}$ & -1.467 & -7.48 & $0.000^{* * *}$ \\
\hline No. of Obs. & 1777 & & & 854 & & \\
\hline F tests & 87.55 & & & 145.43 & & \\
\hline $\mathrm{R}^{2}$ & 0.055 & & & 0.223 & & \\
\hline
\end{tabular}

Notes: This table reports the results of the following regression specification for MSBs and commercial banks for the full sample period: $\ln \left(M S_{i t}\right)=\alpha+\beta \ln \left(M C_{i t}\right)+e_{i t}$

Where $M S$ denotes market shares, $M C$ is marginal costs, and the coefficient $(\beta)$ stands for the Boone index. All tests are based on robust standard errors and the symbols ***, $* *$, and * represent statistical significance at the $1 \%, 5 \%$, and $10 \%$ level, respectively.

In Panel A and B of Table 2, we calculate market shares based on total assets and total loans. Additionally, given that MSBs concentrate their finance on SMEs, the market 
share is re-calculated using total commercial loans for MSBs and total household loans for commercial banks in Panel C of Table 2. Here, Panel C is estimated to check the fact that MSBs and commercial banks formed the competitive relationship centering on real estate PF loans and home mortgage loans during the real estate boom (distinctly, 2005 to 2007), respectively. Findings of this table show that, for all three cases, the coefficients of Boone indices, measures for bank competition, are negatively and significantly correlated with the market shares. The results suggest that, during our sample period, competition pressure in fact exists in both the commercial bank and MSB industry in Korea.

In order to construct panel data, which enable us to examine how bank competition affects the stability of individual financial institutions, we estimate Boone indices on a quarter basis. In Table 3, market shares are calculated based on total assets as well as total loans. The sample periods start on 1999 for commercial banks and on 2003 for MSBs due to data availability. The results show that, for both commercial banks and MSBs, the distributions of Boone indices based on total assets and total loans are qualitatively similar. In the commercial bank industry, Boone indices, coefficients of $\operatorname{Ln}(M C)$, are generally negative and significant in early 2000 with market share of total assets. On the total loans basis, Boone indices are significant until year 2007, consistent with a fact that commercial banks compete fiercely for household loans in mid-2000s due to the housing price boom.6) In the MSB industry, there exists the considerable degree of market pressure during the middle of 2000 when the Korean government relaxed loan regulations drastically in order to support microfinance and promote small loan markets for low-income groups and low-rated SMEs. Also, during this period, real estate PF loans of MSBs increased steeply, resulting from the real estate boom.7)

6) Although the distribution of Boone index on a household loan basis is not reported in Table 3, it is similar to the total loan case. Particularly, the degree of competition (Boone index) in the household loan case turns out to be stronger than that of total loan case. Meanwhile, comparing household loans with corporate lending (commercial loans), we find that competition in household loans is more significant and larger during the period from 2005 to 2007.

7) According to our analyses on the difference between commercial loans and household loans for MSBs, the degree of competition (Boone index) in commercial loans turns out to be larger than that of household loans in mid 2000s. This implies that MSBs extended real estate PF loans more competitively than household loans at that time, compared to domestic commercial banks. 
Table 3: Estimation of quarterly Boone indices

\begin{tabular}{|c|c|c|c|c|c|c|c|c|c|}
\hline \multirow[b]{3}{*}{ Year } & \multirow[b]{3}{*}{ Quarter } & \multicolumn{4}{|c|}{ Commercial banks } & \multicolumn{4}{|c|}{ MSBs } \\
\hline & & \multicolumn{2}{|c|}{$L n(M S)$ in Total Assets } & \multicolumn{2}{|c|}{ Ln(MS) in Total Loans } & \multicolumn{2}{|c|}{$\mathrm{Ln}(M S)$ in Total Assets } & \multicolumn{2}{|c|}{$L n(M S)$ in Total Loans } \\
\hline & & Coef. & t value & Coef. & $t$ value & Coef. & t value & Coef. & $t$ value \\
\hline \multirow[t]{4}{*}{1999} & 1 & -1.464 & $-3.36^{* * *}$ & -1.202 & $-2.91^{* * *}$ & & & & \\
\hline & 2 & -0.177 & -0.49 & -0.097 & -0.25 & & & & \\
\hline & 3 & -0.885 & $-7.34^{* * *}$ & -0.816 & $-6.79^{* * *}$ & & & & \\
\hline & 4 & -0.232 & -0.56 & -0.221 & -0.67 & & & & \\
\hline \multirow[t]{4}{*}{2000} & 1 & -1.104 & $-2.09^{* *}$ & -1.085 & $-2.51^{* *}$ & & & & \\
\hline & 2 & -1.458 & $-5.76^{* * *}$ & -1.379 & $-5.88^{* * *}$ & & & & \\
\hline & 3 & -1.000 & $-10.19^{* * *}$ & -0.982 & $-9.91^{* * *}$ & & & & \\
\hline & 4 & -0.836 & $-2.90^{* * *}$ & -0.848 & $-3.35^{* * *}$ & & & & \\
\hline \multirow[t]{4}{*}{2001} & 1 & -0.713 & -1.11 & -0.800 & -1.41 & & & & \\
\hline & 2 & -1.270 & $-2.24^{* *}$ & -1.363 & $-2.84^{* * *}$ & & & & \\
\hline & 3 & -0.831 & $-3.09^{* * *}$ & -0.859 & $-3.09^{* * *}$ & & & & \\
\hline & 4 & -1.024 & $-2.55^{* *}$ & -1.196 & $-3.85^{* * *}$ & & & & \\
\hline \multirow[t]{4}{*}{2002} & 1 & -0.832 & -1.32 & -1.017 & $-1.92^{*}$ & & & & \\
\hline & 2 & -1.044 & $-2.50^{* *}$ & -1.235 & $-3.94^{* * *}$ & & & & \\
\hline & 3 & -1.171 & $-2.47^{* *}$ & -1.342 & $-3.66^{* * *}$ & & & & \\
\hline & 4 & -1.132 & $-3.17^{* * *}$ & -1.279 & $-4.69^{* * *}$ & & & & \\
\hline \multirow[t]{4}{*}{2003} & 1 & -0.888 & $-1.93^{*}$ & -1.095 & $-3.12^{* * *}$ & & & & \\
\hline & 2 & -1.158 & $-3.18^{* * *}$ & -1.331 & $-5.14^{* * *}$ & & & & \\
\hline & 3 & -0.881 & $-1.91^{*}$ & -1.096 & $-3.29^{* * *}$ & & & & \\
\hline & 4 & -1.038 & $-2.54^{* *}$ & -1.185 & $-3.96^{* * *}$ & -0.151 & -0.35 & -3.315 & $-9.01^{* * *}$ \\
\hline \multirow[t]{4}{*}{2004} & 1 & -0.869 & -1.31 & -1.105 & $-2.07^{* *}$ & -0.275 & -0.69 & -0.396 & -0.94 \\
\hline & 2 & -1.156 & $-1.96^{*}$ & -1.360 & $-3.06^{* * *}$ & -0.568 & -1.30 & -0.888 & $-2.03^{* *}$ \\
\hline & 3 & -1.142 & $-1.96^{*}$ & -1.336 & $-3.03^{* * *}$ & 0.410 & 0.82 & 0.296 & 0.51 \\
\hline & 4 & -0.476 & -0.84 & -0.794 & $-1.73^{*}$ & -0.969 & $-2.23^{* *}$ & -1.235 & $-2.69^{* * *}$ \\
\hline \multirow[t]{4}{*}{2005} & 1 & -0.673 & -0.97 & -0.960 & $-1.71^{*}$ & -0.422 & -1.16 & -0.514 & -1.30 \\
\hline & 2 & -0.879 & -1.28 & -1.150 & $-2.11^{* *}$ & -0.807 & $-2.67^{* * *}$ & -1.275 & $-3.71^{* * *}$ \\
\hline & 3 & -1.024 & -1.52 & -1.259 & $-2.40^{* *}$ & -0.814 & $-3.09^{* * *}$ & -0.980 & $-3.57^{* * *}$ \\
\hline & 4 & -1.053 & $-1.69^{*}$ & -1.324 & $-2.83^{* * *}$ & -0.981 & $-3.20^{* * *}$ & -1.413 & $-4.04^{* * *}$ \\
\hline \multirow[t]{4}{*}{2006} & 1 & -0.576 & -0.88 & -0.892 & -1.63 & -1.127 & $-3.87^{* * *}$ & -1.560 & $-4.85^{* * *}$ \\
\hline & 2 & -0.607 & -0.99 & -0.895 & $-1.96^{*}$ & -1.207 & $-4.62^{* * *}$ & -1.869 & $-5.10^{* * *}$ \\
\hline & 3 & -0.806 & -1.13 & -1.119 & $-2.01^{* *}$ & -1.047 & $-3.64^{* * *}$ & -1.185 & $-4.75^{* * *}$ \\
\hline & 4 & -0.986 & -1.35 & -1.292 & $-2.33^{* *}$ & -1.560 & $-3.90^{* * *}$ & -1.658 & $-3.84^{* * *}$ \\
\hline 2007 & 1 & -0.585 & -0.94 & -0.881 & $-1.85^{*}$ & -1.409 & $-3.51^{* * *}$ & -1.646 & $-3.82^{* * *}$ \\
\hline & 2 & -0.799 & -1.35 & -1.012 & $-2.29^{* *}$ & -0.855 & $-2.18^{* *}$ & -1.473 & $-3.34^{* * *}$ \\
\hline & 3 & -0.611 & -1.19 & -0.842 & $-2.09^{* *}$ & -0.330 & -1.18 & -0.689 & $-3.14^{* * *}$ \\
\hline & 4 & -0.553 & -1.01 & -0.807 & $-1.84^{*}$ & -0.022 & -0.09 & -0.418 & -1.60 \\
\hline 2008 & 1 & -0.141 & -0.38 & -0.414 & -1.32 & 2.043 & $1.95^{*}$ & 1.724 & $1.90^{*}$ \\
\hline & 2 & -0.342 & -0.81 & -0.609 & $-1.70^{*}$ & 1.548 & 1.30 & 1.173 & 1.11 \\
\hline & 3 & 0.000 & 0.00 & -0.288 & -1.02 & -1.069 & -1.28 & -0.930 & -1.01 \\
\hline & 4 & 0.469 & 1.44 & 0.162 & 0.51 & 1.133 & 0.81 & 1.048 & 0.72 \\
\hline 2009 & 1 & 0.439 & $1.69^{*}$ & 0.125 & 0.47 & -0.125 & -0.20 & -0.127 & -0.20 \\
\hline & 2 & -0.651 & -1.12 & -0.860 & -1.60 & 0.331 & 0.27 & -0.033 & -0.03 \\
\hline & 3 & -0.460 & -0.67 & -0.749 & -1.24 & 0.358 & 0.87 & -0.025 & -0.05 \\
\hline & 4 & -0.618 & -1.06 & -0.826 & -1.56 & 0.008 & 0.02 & -0.499 & -1.13 \\
\hline 2010 & 1 & -0.273 & -0.52 & -0.556 & -1.11 & -0.228 & -0.51 & -0.632 & -1.64 \\
\hline & 2 & -0.138 & -0.23 & -0.407 & -0.71 & -0.808 & -1.12 & -1.312 & $-2.00^{* *}$ \\
\hline & 3 & -0.751 & -1.12 & -0.991 & -1.64 & -0.527 & -0.75 & -0.707 & -0.89 \\
\hline & 4 & -1.438 & $-1.93^{*}$ & -1.637 & $-2.50^{* *}$ & -0.026 & -0.02 & -0.311 & -0.22 \\
\hline 2011 & 1 & -0.111 & -0.25 & -0.253 & -0.63 & -0.995 & -0.77 & -1.437 & -1.13 \\
\hline & 2 & -0.185 & -0.40 & -0.344 & -0.82 & -1.176 & -1.06 & -1.748 & $-1.80^{*}$ \\
\hline & 3 & 0.602 & 1.40 & 0.427 & 1.00 & -0.090 & -0.08 & -0.290 & -0.25 \\
\hline & 4 & 0.011 & 0.02 & -0.110 & -0.19 & -0.489 & -0.89 & -0.972 & $-1.86^{*}$ \\
\hline & & & Quarter dum & s Include & & & Quarter du & s include & \\
\hline & $R^{2}$ & & & & & & & & \\
\hline
\end{tabular}

Notes: The table reports the estimation of quarterly Boone indices by estimating the following regression specification for MSBs and commercial banks: $\ln \left(M S_{i t}\right)=\alpha+\sum_{t=1999 \mathrm{Q}}^{201124} \beta_{t} \ln \left(M C_{i t}\right) \times$ Quarter Dummy $y_{t}+\delta_{t}$ Quarter Dummy $y_{t}+\varepsilon_{i t}$

The coefficient $(\beta)$ stands for the Boone index. The symbols ***, **, and * represent statistical significance at the $1 \%, 5 \%$, and $10 \%$ level, respectively. 


\section{Competition and stability in the MSB industry}

Before conducting regression analyses, we first take an initial look at correlations between independent variables. By obtaining the correlation coefficients between such figures, we should be aware of potential multicollinearity. As reported in Table 4, in the MSB sample, all the correlation coefficients except for that (0.573) between competition and Inverse of Boone Index ${ }^{8)}$ are relatively very low. In the commercial bank case, also, all the coefficients except for it (0.894) are not high. As a result, we conclude that the correlation coefficients between explanatory variables are rather small and thus muticollinearity may not affect the results of our regressions.

\section{Table 4: Correlation coefficients matrix between main variables}

Panel A. MSBs

\begin{tabular}{l|c|c|c|c|c} 
& Competition & $\begin{array}{c}\text { Inverse of } \\
\text { Boone Index }\end{array}$ & Ln(Assets) & Profit ratio & $\begin{array}{c}\text { Loan to } \\
\text { Deposit }\end{array}$ \\
\hline Competition & 1 & & & & \\
\hline Inverse of Boone Index & 0.573 & 1 & & & \\
\hline Ln(Assets) & -0.134 & -0.105 & 1 & & \\
\hline Profit ratio & 0.057 & 0.037 & -0.015 & 1 & 1 \\
\hline Loan to Deposit & 0.091 & 0.040 & 0.006 & 0.118 & 1 \\
\hline Commercial to Home loan & -0.121 & -0.088 & 0.386 & -0.034 & 0.046 \\
\hline
\end{tabular}

Panel B. Commercial banks

\begin{tabular}{l|c|c|c|c|c} 
& Competition & $\begin{array}{c}\text { Inverse of } \\
\text { Boone Index }\end{array}$ & Ln(Assets) & Profit ratio & $\begin{array}{c}\text { Loan to } \\
\text { Deposit }\end{array}$ \\
\hline Competition & 1 & & & & \\
\hline Inverse of Boone Index & 0.894 & 1 & & & \\
\hline Ln(Assets) & -0.145 & -0.155 & 1 & & \\
\hline Profit ratio & -0.203 & -0.164 & 0.075 & 1 & 1 \\
\hline Loan to Deposit & -0.168 & -0.177 & 0.361 & 0.076 & 0.244 \\
\hline Commercial to Home loan & -0.049 & -0.061 & 0.185 & 0.032 & 0.2 \\
\hline
\end{tabular}

Notes: This table contains Pearson correlation coefficients matrix for the variables used in our main analyses. All of the variables are discussed in the third part of Table 1.

8) Because of multicollinearity problems between Competition and Inverse of Boone Index, we intend to estimate our following regression models separately, when those two variables are used. 
Using the Boone indices and concentration measures estimated in the previous sections, we examine the effect of competition on stability in the MSB industry. We conduct OLS regressions as a baseline-model as well as panel analysis to control for time invariant heterogeneity of each bank. Table 5 reports the results of our regressions where the dependent variables in Panel A and Panel B are the $Z$ - scores using ROAs for prior four quarters and for prior eight quarters, respectively. The key independent variables are a dummy for the presence of market pressure (Competition) and the opposite of Boone indices (Inverse of Boone Index). The significant and positive coefficients on Competition and Inverse of Boone Index in both OLS and fixed effects models suggest that the probability of MSB defaults are lower in the competitive market, consistent with our hypothesis that higher interest rates charged by MSBs in a less competitive market would increase the risk-taking behavior of borrowers, most of whom are SMEs possessing greater business and credit risk (Boyd and De Nicolo, 2005). In the words of Martinez-Miera and Repullo (2010), the risk shifting effect overwhelms the interest effect for MSBs when the market is less competitive or more concentrated.

Note that most of the coefficients of our control variables are signed in accordance with our expectations and prior literature. The profit ratio is positively correlated with MSB stability. The loan to deposit ratio increases the stability of MSBs but the negative effect of the squared loan to deposit ratio suggests that its increasing rate in fact decreases. Market volatility, measured by $C D$ volatility, significantly increases the defaults of MSBs.

\section{Table 5: Effects of competition on stability in the MSB industry}

Panel A. Analysis of $Z-$ score with the ROAs for prior four quarters

\begin{tabular}{|c|c|c|c|c|c|c|c|c|}
\hline \multirow{2}{*}{$\operatorname{Ln}\left(Z_{4}\right)$} & \multicolumn{4}{|c|}{ OLS } & \multicolumn{4}{|c|}{ Fixed Effects } \\
\hline & Coef. & t-value & Coef. & t-value & Coef. & t-value & Coef. & t-value \\
\hline Competition & 0.4987 & {$[8.88]^{* * *}$} & & & 0.5551 & {$[6.87]^{* * *}$} & & \\
\hline Inverse of Boone Index & & & 0.2716 & {$[7.92]^{* * *}$} & & & 0.2756 & {$[6.18]^{* * *}$} \\
\hline Ln(Assets) & -0.0357 & {$[-1.23]$} & -0.0410 & {$[-1.40]$} & 0.0120 & {$[0.08]$} & -0.1399 & {$[-0.97]$} \\
\hline Profit ratio & 0.0042 & {$[2.10]^{* *}$} & 0.0043 & {$[2.11]^{* *}$} & 0.0035 & {$[1.96]^{*}$} & 0.0036 & {$[1.93]^{*}$} \\
\hline Loan to Deposit & 0.0465 & {$[3.92]^{* * *}$} & 0.0455 & {$[3.72]^{* * *}$} & 0.0567 & {$[1.59]$} & 0.0544 & [1.52] \\
\hline Loan to Deposit ${ }^{2}$ & -0.0002 & {$[-3.29]^{* * *}$} & -0.0002 & {$[-3.03]^{* * *}$} & -0.0003 & {$[-1.45]$} & -0.0002 & {$[-1.31]$} \\
\hline Commercial to Home loan & 0.0019 & {$[1.37]$} & 0.0013 & {$[0.87]$} & -0.0074 & {$[-1.70]^{*}$} & -0.0083 & {$[-1.85]^{*}$} \\
\hline$C D$ Volatility & -0.1801 & {$[-2.95]^{* * *}$} & -0.2921 & {$[-4.98]^{* * *}$} & -0.1878 & {$[-2.64]^{* * *}$} & -0.2785 & {$[-3.81]^{* * *}$} \\
\hline Intercept & -1.7630 & {$[-3.04]^{* * *}$} & -1.5559 & {$[-2.62]^{* * *}$} & -2.5086 & {$[-1.25]$} & -1.1059 & {$[-0.55]$} \\
\hline No. of Obs. & \multicolumn{2}{|c|}{2,137} & \multicolumn{2}{|c|}{2,137} & \multicolumn{2}{|c|}{2,137} & \multicolumn{2}{|c|}{2,137} \\
\hline F/Wald tests & \multicolumn{2}{|c|}{24.95} & \multicolumn{2}{|c|}{21.29} & \multicolumn{2}{|c|}{14.68} & \multicolumn{2}{|c|}{12.38} \\
\hline $\mathrm{R}^{2}$ & \multicolumn{2}{|c|}{0.084} & \multicolumn{2}{|c|}{0.074} & \multicolumn{2}{|c|}{0.072} & \multicolumn{2}{|c|}{0.052} \\
\hline
\end{tabular}


Panel B. Analysis of $Z$-score with the ROAs for prior eight quarters

\begin{tabular}{|c|c|c|c|c|c|c|c|c|}
\hline \multirow{2}{*}{$\operatorname{Ln}\left(Z_{8}\right)$} & \multicolumn{4}{|c|}{ OLS } & \multicolumn{4}{|c|}{ Fixed Effects } \\
\hline & Coef. & t-value & Coef. & t-value & Coef. & t-value & Coef. & t-value \\
\hline Competition & 0.5543 & {$[9.73]^{* * *}$} & & & 0.6905 & {$[7.75]^{* * *}$} & & \\
\hline Inverse of Boone Index & & & 0.2614 & {$[7.65]^{* * *}$} & & & 0.2847 & {$[6.71]^{* * *}$} \\
\hline $\operatorname{Ln}($ Assets $)$ & -0.0024 & {$[-0.08]$} & -0.0106 & {$[-0.37]$} & 0.2352 & {$[1.22]$} & -0.0464 & {$[-0.27]$} \\
\hline Profit ratio & 0.0059 & {$[2.17]^{* *}$} & 0.0059 & {$[2.15]^{* *}$} & 0.0056 & {$[2.06]^{* *}$} & 0.0056 & {$[2.05]^{* *}$} \\
\hline Loan to Deposit & 0.0526 & {$[3.88]^{* * *}$} & 0.0514 & {$[3.80]^{* * *}$} & 0.0684 & {$[2.21]^{* *}$} & 0.0731 & {$[2.41]^{* *}$} \\
\hline Loan to Deposit ${ }^{2}$ & -0.0002 & {$[-3,16]^{* * *}$} & -0.0002 & {$[-2.95]^{* * *}$} & -0.0003 & {$[-1.83]^{*}$} & -0.0003 & {$[-1.88]^{*}$} \\
\hline Commercial to Home loan & 0.0002 & {$[0.18]$} & -0.0004 & {$[-0.32]$} & -0.0061 & {$[-1.74]^{*}$} & -0.0075 & {$[-1.92]^{*}$} \\
\hline$C D$ Volatility & -0.1574 & {$[-2.51]^{* *}$} & -0.2665 & {$[-4.43]^{* * *}$} & -0.1685 & {$[-2.36]^{* *}$} & -0.2626 & {$[-3.61]^{* * *}$} \\
\hline Intercept & -2.8477 & {$[-4.37]^{* * *}$} & -2.6309 & {$[-4.05]^{* * *}$} & -5.6183 & {$[-2.89]^{* * *}$} & -3.5127 & {$[-1.95]^{*}$} \\
\hline No. of Obs. & \multicolumn{2}{|c|}{1,764} & \multicolumn{2}{|c|}{1,764} & \multicolumn{2}{|c|}{1,764} & \multicolumn{2}{|c|}{1,764} \\
\hline F/Wald tests & \multicolumn{2}{|c|}{27.87} & \multicolumn{2}{|c|}{21.83} & \multicolumn{2}{|c|}{16.90} & \multicolumn{2}{|c|}{15.14} \\
\hline$R^{2}$ & \multicolumn{2}{|c|}{0115} & \multicolumn{2}{|c|}{0.097} & \multicolumn{2}{|c|}{0.090} & \multicolumn{2}{|c|}{0.084} \\
\hline
\end{tabular}

Notes: OLS and panel regressions are estimated for the stability of MSBs. The dependent variable is the $Z$-scores of MSBs using the ROAs for prior four (Panel A) or eight (Panel B) quarters. All tests use robust standard errors and t-statistics are reported in brackets. The symbols $* * *, * *$, and * represent statistical significance at the $1 \%, 5 \%$, and $10 \%$ level, respectively. The descriptions of variables are provided in the third part of Table 1.

In Table 6, we additionally investigate a relationship between concentration and stability in the MSB market. Also, we intend to consider the fact that the MSB industry has faced serious default problems of existing loans (for example, real estate PF loans) under the low competitive environment since the recent global financial crisis because of the sluggishness in real estate markets. $\left.{ }^{9}\right)$ At that time, many MSBs failed to find new profit sources and therefore bank competition did not be strongly formed. According to

9) We intend to investigate concentration risk indirectly through these analyses. Many MSBs extended their real estate PF loans competitively during the housing boom, notably from 2005 to 2007 . This can be found in Table 3. As a result of the competitive relationship in the past, some large-sized MSBs (for example, Busan mutual savings banks) became to hold most of total real estate PF loans. 29 MSBs with total asset one trillion won occupied around $80 \%$ of all MSBs' PF loans (12.3 trillion won) in end-2010. At that time, the total number of MSBs was 105 banks and the proportion of large-sized MSBs (29 banks) with total asset one trillion won was $27.6 \%$ of all MSBs. Therefore, the concentration degree in the MSB industry had gone up sharply until 2010. Subsequently, default risks have increased around those MSBs with higher PF loans. 20 banks were ordered to suspend business between 2011 and 2012. During this period, Korean construction business and housing markets continued on a downward trend. Deeply influenced by these situations, many MSBs suffered from difficulties. A series of these phenomena imply that higher concentration in the MSB industry whose customers are mainly composed of low-rated and vulnerable borrowers may lead to raising default risks at the time of business recession. In particular, since some MSBs were exposed excessively to real estate PF loans, they could not help but be more influenced by business cycle. 
the structure-conduct-performance $(S C P)$ view, the number of firms and their market shares determine the competitive level of the industry. $C R$ and $H H I$, discussed in Section III-2, are used as proxies of market concentration and, more specifically, $C R_{4}$ and $C R_{8}$ represent the concentration ratio by top four and eight banks, respectively. As in the previous Table 5, we use the $Z$ - scores as the dependent variables and estimate OLS and fixed effects regressions. The results of Table 6 show that the coefficients for the concentration measure are significantly negative, consistent with the results in Table 5 . In general, greater concentration ratios imply less competitive markets. We, however, find that the squared terms of concentration ratios are positively correlated with the $Z$-scores, which suggests that the relationship between market concentration and MSB stability is in fact nonlinear. The coefficients of control variables are signed consistently with the previous table.

\section{Table 6: Effects of concentration on stability in the MSB industry}

Panel A. Analysis of $Z$-score with the ROAs for prior four quarters

\begin{tabular}{|c|c|c|c|c|c|c|c|c|}
\hline \multirow[b]{2}{*}{$\operatorname{Ln}\left(Z_{4}\right)$} & \multicolumn{4}{|c|}{ OLS } & \multicolumn{4}{|c|}{ Fixed Effects } \\
\hline & $\begin{array}{c}\text { Coef. } \\
\text { [t-value] }\end{array}$ & $\begin{array}{c}\text { Coef. } \\
\text { [t-value] }\end{array}$ & $\begin{array}{c}\text { Coef. } \\
\text { [t-value] }\end{array}$ & $\begin{array}{c}\text { Coef. } \\
\text { [t-value] }\end{array}$ & $\begin{array}{c}\text { Coef. } \\
\text { [t-value] }\end{array}$ & $\begin{array}{c}\text { Coef. } \\
\text { [t-value] }\end{array}$ & $\begin{array}{c}\text { Coef. } \\
\text { [t-value] }\end{array}$ & $\begin{array}{c}\text { Coef. } \\
\text { [t-value] }\end{array}$ \\
\hline$C R_{4}$ & $\begin{array}{l}-0.1288^{* * *} \\
{[-7.38]}\end{array}$ & $\begin{array}{l}-1.8701^{* *} \\
{[-2.25]}\end{array}$ & & & $\begin{array}{c}-0.1735^{* * *} \\
{[-4.42]}\end{array}$ & $\begin{array}{c}-2.1478^{* *} \\
{[-2.32]}\end{array}$ & & \\
\hline$\left(C R_{4}\right)^{2}$ & & $\begin{array}{l}0.0274^{* *} \\
{[2.10]}\end{array}$ & & & & $\begin{array}{l}0.0314^{* *} \\
{[2.15]}\end{array}$ & & \\
\hline$H H I$ & & & $\begin{array}{l}-0.0122^{* * *} \\
{[-6.22]}\end{array}$ & $\begin{array}{c}-0.5760^{* * *} \\
{[-7.15]}\end{array}$ & & & $\begin{array}{l}-0.0160^{* * *} \\
{[-3.39]}\end{array}$ & $\begin{array}{l}-0.5849^{* * *} \\
{[-6.38]}\end{array}$ \\
\hline$H H I^{2}$ & & & & $\begin{array}{l}0.0013^{* * *} \\
{[7.01]}\end{array}$ & & & & $\begin{array}{l}0.0013^{* * *} \\
{[6.21]}\end{array}$ \\
\hline $\operatorname{Ln}($ Assets $)$ & $\begin{array}{r}-0.0309 \\
{[-1.06]}\end{array}$ & $\begin{array}{r}-0.0303 \\
{[-1.03]}\end{array}$ & $\begin{array}{r}-0.0344 \\
{[-1.17]}\end{array}$ & $\begin{array}{r}-0.0311 \\
{[-1.06]}\end{array}$ & $\begin{array}{r}0.1579 \\
{[0.84]}\end{array}$ & $\begin{array}{c}0.0401 \\
{[0.73]}\end{array}$ & $\begin{array}{r}0.0774 \\
{[0.40]}\end{array}$ & $\begin{array}{r}0.0339 \\
{[0.60]}\end{array}$ \\
\hline Profit ratio & $\begin{array}{l}0.0041^{* *} \\
{[2.05]}\end{array}$ & $\begin{array}{l}0.0041^{* *} \\
{[2.09]}\end{array}$ & $\begin{array}{l}0.0043^{* *} \\
{[2.12]}\end{array}$ & $\begin{array}{l}0.0040^{* *} \\
{[2.04]}\end{array}$ & $\begin{array}{c}0.0033^{*} \\
{[1.85]}\end{array}$ & $\begin{array}{l}0.0037^{* *} \\
{[2.07]}\end{array}$ & $\begin{array}{l}0.0036^{*} \\
{[1.95]}\end{array}$ & $\begin{array}{l}0.0036^{* *} \\
{[2.05]}\end{array}$ \\
\hline Loan to Deposit & $\begin{array}{l}0.0458^{* * *} \\
{[4.07]}\end{array}$ & $\begin{array}{l}0.0456^{* * *} \\
{[4.01]}\end{array}$ & $\begin{array}{l}0.0460^{* * *} \\
{[4.06]}\end{array}$ & $\begin{array}{l}0.0451^{* * *} \\
{[3.75]}\end{array}$ & $\begin{array}{c}0.0543 \\
{[1.54]}\end{array}$ & $\begin{array}{c}0.0525^{*} \\
{[1.88]}\end{array}$ & $\begin{array}{r}0.0548 \\
{[1.54]}\end{array}$ & $\begin{array}{l}0.0527^{*} \\
{[1.82]}\end{array}$ \\
\hline Loan to Deposit ${ }^{2}$ & $\begin{array}{l}-0.0002^{* * *} \\
{[-3.53]}\end{array}$ & $\begin{array}{c}-0.0002^{* * *} \\
{[-3.44]}\end{array}$ & $\begin{array}{l}-0.0002^{* * *} \\
{[-3.48]}\end{array}$ & $\begin{array}{c}-0.0002^{* * *} \\
{[-3.07]}\end{array}$ & $\begin{array}{r}-0.0003 \\
{[-1.53]}\end{array}$ & $\begin{array}{c}-0.0003^{*} \\
{[-1.72]}\end{array}$ & $\begin{array}{r}-0.0003 \\
{[-1.50]}\end{array}$ & $\begin{array}{c}-0.0002 \\
{[-1.58]}\end{array}$ \\
\hline $\begin{array}{l}\text { Commercial to } \\
\text { Home loan }\end{array}$ & $\begin{array}{c}0.0024^{*} \\
{[1.72]}\end{array}$ & $\begin{array}{r}0.0023 \\
{[1.61]}\end{array}$ & $\begin{array}{r}0.0021 \\
{[1.46]}\end{array}$ & $\begin{array}{r}0.0019 \\
{[1.38]}\end{array}$ & $\begin{array}{r}-0.0063 \\
{[-1.41]}\end{array}$ & $\begin{array}{r}-0.0034 \\
{[-0.96]}\end{array}$ & $\begin{array}{r}-0.0069 \\
{[-1.52]}\end{array}$ & $\begin{array}{c}-0.0041 \\
{[-1.22]}\end{array}$ \\
\hline$C D$ Volatility & $\begin{array}{l}-0.2215^{* * *} \\
{[-3.61]}\end{array}$ & $\begin{array}{c}-0.1797^{* * *} \\
{[-2.80]}\end{array}$ & $\begin{array}{l}-0.2502^{* * *} \\
{[-4.12]}\end{array}$ & $\begin{array}{r}-0.0681 \\
{[-1.04]}\end{array}$ & $\begin{array}{c}-0.2407^{* * *} \\
{[-3.35]}\end{array}$ & $\begin{array}{c}-0.1824^{* * *} \\
{[-2.66]}\end{array}$ & $\begin{array}{l}-0.2610^{* * *} \\
{[-3.61]}\end{array}$ & $\begin{array}{r}-0.0748 \\
{[-1.12]}\end{array}$ \\
\hline Intercept & $\begin{array}{l}2.5578^{* * *} \\
{[3.31]}\end{array}$ & $\begin{array}{c}30.1039^{* *} \\
{[2.29]}\end{array}$ & $\begin{array}{c}1.1709^{*} \\
{[1.68]}\end{array}$ & $\begin{array}{c}62.8115^{* * *} \\
{[7.14]}\end{array}$ & $\begin{array}{r}2.3239 \\
{[1.18]}\end{array}$ & $\begin{array}{c}33.9917^{* *} \\
{[2.34]}\end{array}$ & $\begin{array}{l}0.9291 \\
{[0.47]}\end{array}$ & $\begin{array}{c}\text { 63.1114*** } \\
{[6.42]}\end{array}$ \\
\hline No. of Obs. & 2,137 & 2,137 & 2,137 & 2,137 & 2,137 & 2,137 & 2,137 & 2,137 \\
\hline F/Wald tests & 22.93 & 20.27 & 20.18 & 21.95 & 12.41 & 92.18 & 10.89 & 94.76 \\
\hline$R^{2}$ & 0.075 & 0.076 & 0.067 & 0.088 & 0.055 & 0.070 & 0.061 & 0.081 \\
\hline
\end{tabular}


Panel B. Analysis of $Z$-score with the ROAs for prior eight quarters

\begin{tabular}{|c|c|c|c|c|c|c|c|c|}
\hline \multirow{2}{*}{$\operatorname{Ln}\left(Z_{8}\right)$} & \multicolumn{4}{|c|}{ OLS } & \multicolumn{4}{|c|}{ Fixed Effects } \\
\hline & Coef. & t-value & Coef. & t-value & Coef. & t-value & Coef. & t-value \\
\hline$C R_{8}$ & -0.1274 & {$[-7.10]^{* * *}$} & & & -0.1818 & {$[-4.40]^{* * *}$} & & \\
\hline$H H I$ & & & -0.0106 & {$[-5.16]^{* * *}$} & & & -0.0136 & {$[-2.80]^{* * *}$} \\
\hline $\operatorname{Ln}($ Assets $)$ & -0.0018 & {$[-0.06]$} & -0.0089 & {$[-0.31]$} & 0.2777 & {$[1.22]$} & 0.0700 & {$[0.31]$} \\
\hline Profit ratio & 0.0057 & {$[2.13]^{* *}$} & 0.0060 & {$[2.18]^{* *}$} & 0.0052 & {$[1.95]^{*}$} & 0.0055 & {$[2.03]^{* *}$} \\
\hline Loan to Deposit & 0.0539 & {$[4.28]^{* * *}$} & 0.0541 & {$[4.23]^{* * *}$} & 0.0658 & {$[1.99]^{*}$} & 0.0695 & {$[2.10]^{* *}$} \\
\hline Loan to Deposit ${ }^{2}$ & -0.0002 & {$[-3.59]^{* * *}$} & -0.0002 & {$[-3.49]^{* * *}$} & -0.0003 & {$[-1.78]^{*}$} & -0.0003 & {$[-1.80]^{*}$} \\
\hline Commercial to Home loan & 0.0005 & {$[0.39]$} & 0.0000 & {$[0.03]$} & -0.0054 & {$[-1.45]$} & -0.0065 & {$[-1.59]$} \\
\hline$C D$ Volatility & -0.2159 & {$[-3.48]^{* * *}$} & -0.2527 & {$[-4.11]^{* * *}$} & -0.2346 & {$[-3.28]^{* * *}$} & -0.2609 & {$[-3.59]^{* * *}$} \\
\hline Intercept & 1.4092 & {$[1.68]^{*}$} & -0.2816 & {$[-0.37]$} & 0.4300 & {$[0.24]$} & -0.9431 & {$[-0.52]$} \\
\hline No. of Obs. & \multicolumn{2}{|c|}{1,764} & \multicolumn{2}{|c|}{1,764} & \multicolumn{2}{|c|}{1,764} & \multicolumn{2}{|c|}{1,764} \\
\hline $\mathrm{F} /$ Wald tests & \multicolumn{2}{|c|}{22.58} & \multicolumn{2}{|c|}{18.24} & \multicolumn{2}{|c|}{10.17} & \multicolumn{2}{|c|}{8.42} \\
\hline$R^{2}$ & \multicolumn{2}{|c|}{0.097} & \multicolumn{2}{|c|}{0.083} & \multicolumn{2}{|c|}{0.068} & \multicolumn{2}{|c|}{0.074} \\
\hline
\end{tabular}

Notes: OLS and panel regressions are estimated for the stability of MSBs as a function of the concentration level. The dependent variable and other description are the same as Table 5. All tests use robust standard errors and t-statistics are reported in brackets. The symbols $* * *, * *$, and $*$ represent statistical significance at the $1 \%, 5 \%$, and $10 \%$ level, respectively.

\section{Competition and stability in the commercial bank industry}

In this section, we examine whether the relationship between competition and stability is different between MSBs and commercial banks. Table 7 reports estimates of OLS and panel regressions on the $Z$ - scores of commercial banks as a function of the measures for market competition. In the first regression of Panel A, where the key independent variable is Competition, a dummy for the presence of competitive pressure, its negative and significant coefficient implies that, consistent with the competition-fragility view, the presence of competition significantly increases the probability of bank defaults. In the second regression, the level of competition, measured by Inverse of Boone Index, is negatively correlated with the $Z$ - score, while its squared term has a positive effect. That is, market competition significantly decreases the stability of commercial banks, but the effect is nonlinear, consistent with a nonlinear U-shaped relationship between competition and stability suggested by Tabak, Fazio, and Cajueiro (2012). This nonlinear relationship is also found in the study of MartinezMiera and Repullo (2010). They, however, suggest that a nonlinear U-shaped relationship between competition and bank risk-taking (i.e. instability of bank). The results of Panel A are qualitatively similar to those of Panel B in which the $Z-$ score 
with the ROAs for prior eight quarters is used. ${ }^{10)}$

Table 7: Effects on competition on stability in the commercial bank industry

Panel A. Analysis of $Z$-score with the ROAs for prior four quarters

\begin{tabular}{|c|c|c|c|c|c|c|c|c|}
\hline \multirow{2}{*}{$\operatorname{Ln}\left(Z_{4}\right)$} & \multicolumn{4}{|c|}{ OLS } & \multicolumn{4}{|c|}{ Random Effects } \\
\hline & Coef. & $\mathrm{t}$-value & Coef. & $t$-value & Coef. & $z$-value & Coef. & $z$-value \\
\hline Competition & -0.5224 & {$[-5.77]^{* * *}$} & & & -0.3989 & {$[-5,17]^{* * *}$} & & \\
\hline Inverse of Boone Index & & & -1.0715 & {$[-3.43]^{* * *}$} & & & -0.5305 & {$[-2.45]^{* *}$} \\
\hline Inverse of Boone Index ${ }^{2}$ & & & 0.5037 & {$[1.79]^{*}$} & & & 0.1764 & {$[1.20]$} \\
\hline Ln(Assets) & -0.1554 & {$[-3.92]^{* * *}$} & -0.1552 & {$[-3.95]^{* * *}$} & 0.3811 & {$[2.28]^{* *}$} & 0.5541 & {$[2.98]^{* * *}$} \\
\hline Profit ratio & 3.7195 & {$[5.22]^{* * *}$} & 3.8649 & {$[5.48]^{* * *}$} & 3.5188 & {$[4.43]^{* * *}$} & 3.6598 & {$[4.85]^{* * *}$} \\
\hline Foreign & 0.6560 & {$[5.06]^{* *}$} & 0.6556 & {$[5.05]^{* * *}$} & 0.5303 & {$[1.69]^{*}$} & 0.4775 & [1.33] \\
\hline Loan to Deposit & 0.0367 & {$[8.18]^{* * *}$} & 0.0352 & {$[7.89]^{* * *}$} & 0.0329 & {$[2.44]^{* *}$} & 0.0296 & {$[2.25]^{* *}$} \\
\hline Loan to Deposit ${ }^{2}$ & -0.0001 & {$[-6.91]^{* * *}$} & -0.0001 & {$[-6.64]^{* * *}$} & -0.0001 & {$[-2.29]^{* *}$} & -0.0001 & {$[-2.18]^{* *}$} \\
\hline Commercial to Home loan & 0.0004 & [1.44] & 0.0003 & [1.21] & 0.0007 & {$[1.10]$} & 0.0007 & [1.06] \\
\hline$C D$ Volatility & -0.1230 & {$[-1,11]$} & -0.2707 & {$[-2.28]^{* *}$} & -0.1994 & {$[-1.34]$} & -0.2971 & {$[-1.97]^{* *}$} \\
\hline Intercept & 3.6527 & {$[6.44]^{* * *}$} & 3.8079 & {$[6.78]^{* * *}$} & -5.3765 & {$[-2.30]^{* *}$} & -8.1030 & {$[-3.03]^{* * *}$} \\
\hline No. of Obs. & \multicolumn{2}{|c|}{738} & \multicolumn{2}{|c|}{738} & \multicolumn{2}{|c|}{738} & \multicolumn{2}{|c|}{738} \\
\hline F/Wald tests & \multicolumn{2}{|c|}{32.16} & \multicolumn{2}{|c|}{29.52} & \multicolumn{2}{|c|}{443.36} & \multicolumn{2}{|c|}{473.39} \\
\hline $\mathrm{R}^{2}$ & \multicolumn{2}{|c|}{0.240} & \multicolumn{2}{|c|}{0.249} & \multicolumn{2}{|c|}{0.329} & \multicolumn{2}{|c|}{0.350} \\
\hline
\end{tabular}

Panel B. Analysis of $Z$-score with the ROAs for prior eight quarters

\begin{tabular}{|c|c|c|c|c|c|c|c|c|}
\hline \multirow{2}{*}{$\operatorname{Ln}\left(Z_{8}\right)$} & \multicolumn{4}{|c|}{ OLS } & \multicolumn{4}{|c|}{ Random Effects } \\
\hline & Coef. & t-value & Coef. & t-value & Coef. & $z$-value & Coef. & $z$-value \\
\hline Competition & -0.5812 & {$[-6.79]^{* * *}$} & & & -0.4712 & {$[-5,14]^{* * *}$} & & \\
\hline Inverse of Boone Index & & & -1.6732 & {$[-6.29]^{* * *}$} & & & -1.1938 & {$[-5.27]^{* * *}$} \\
\hline Inverse of Boone Index ${ }^{2}$ & & & 0.9888 & {$[4.09]^{* * *}$} & & & 0.6597 & {$[3.74]^{* * *}$} \\
\hline $\operatorname{Ln}($ Assets $)$ & -0.1555 & {$[-4.17]^{* * *}$} & -0.1559 & {$[-4.25]^{* * *}$} & 0.3199 & {$[1.70]^{*}$} & 0.3393 & {$[1.77]^{*}$} \\
\hline Profit ratio & 1.9727 & {$[2.57]^{* *}$} & 2.2290 & {$[2.96]^{* * *}$} & 1.7940 & {$[2.06]^{* *}$} & 2.0102 & {$[2.41]^{* *}$} \\
\hline Foreign & 0.5775 & {$[4.65]^{* * *}$} & 0.5796 & {$[4.80]^{* * *}$} & 0.4631 & {$[1.48]$} & 0.4515 & {$[1.43]$} \\
\hline Loan to Deposit & 0.0303 & {$[7.87]^{* * *}$} & 0.0280 & {$[7.36]^{* * *}$} & 0.0279 & {$[2.02]^{* *}$} & 0.0250 & {$[1.94]^{*}$} \\
\hline Loan to Deposit ${ }^{2}$ & -0.0001 & {$[-6.41]^{* * *}$} & -0.0001 & {$[-5.74]^{* * *}$} & -0.0001 & {$[-1,82]^{*}$} & -0.0001 & {$[-1.74]^{*}$} \\
\hline Commercial to Home loan & 0.0001 & {$[0.66]$} & 0.0001 & {$[0.26]$} & 0.0005 & {$[0.81]$} & 0.0005 & {$[0.72]$} \\
\hline$C D$ Volatility & -0.2519 & {$[-2.22]^{* *}$} & -0.4390 & {$[-3.65]^{* * *}$} & -0.3248 & {$[-3.98]^{* * *}$} & -0.4664 & {$[-6.26]^{* * *}$} \\
\hline Intercept & 3.9713 & {$[7.47]^{* * *}$} & 4.2033 & {$[8.07]^{* * *}$} & -4.1093 & {$[-1.57]$} & -4.1711 & {$[-1.54]$} \\
\hline No. of Obs. & \multicolumn{2}{|c|}{682} & \multicolumn{2}{|c|}{682} & \multicolumn{2}{|c|}{682} & \multicolumn{2}{|c|}{682} \\
\hline F/Wald tests & \multicolumn{2}{|c|}{30.08} & \multicolumn{2}{|c|}{29.83} & \multicolumn{2}{|c|}{443.48} & \multicolumn{2}{|c|}{713.57} \\
\hline $\mathrm{R}^{2}$ & \multicolumn{2}{|c|}{0.223} & \multicolumn{2}{|c|}{0.251} & \multicolumn{2}{|c|}{0.343} & \multicolumn{2}{|c|}{0.359} \\
\hline
\end{tabular}

Notes: OLS and panel regressions are estimated for the stability of commercial banks. The dependent variable and other description are the same as Table 5 . All tests use robust standard errors and $t / z$-statistics are reported in brackets. The symbols $* * *, * *$, and * represent statistical significance at the $1 \%, 5 \%$, and $10 \%$ level, respectively.

10) We employ random effects models rather than fixed effects models for the panel analysis of Table 7 in order to estimate the effect of foreign banks (the dummy variable of Foreign). Note that fixed effects regressions do not provide estimates for time-invariant variables such as the Foreign. We also conduct fixed effects regressions and their results, as shown below, are similar to those of Table 7 which is driven by random effects models. More detailed results are available upon request.

\begin{tabular}{l|c|c|c|c|r|r|r|r|r}
$\operatorname{Ln}\left(Z_{4}\right)$ & $\begin{array}{c}\text { Inverse of } \\
\text { Boone }\end{array}$ & $\begin{array}{c}\text { Inverse of } \\
\text { Boone }\end{array}$ & $\begin{array}{l}\mathrm{Ln}(\text { Assets) } \\
\text { Profit } \\
\text { ratio }\end{array}$ & $\begin{array}{c}\text { Loan to } \\
\text { Deposit }\end{array}$ & $\begin{array}{c}\text { Loan to } \\
\text { Deposit }\end{array}$ & $\begin{array}{c}\text { Commercial to } \\
\text { Home loan }\end{array}$ & CD Volatility & Intercept \\
\hline Coef. & -0.2920 & 0.2820 & -2.0130 & 3.8959 & 0.0080 & 0.0000 & 0.0005 & -0.2897 & -31.7132 \\
\hline$P$ & $0.06^{*}$ & $0.02^{* *}$ & $0.00^{* *}$ & $0.00^{* *}$ & 0.58 & 0.22 & 0.32 & $0.08^{*}$ & $0.00^{* *}$ \\
\hline
\end{tabular}

No. of Obs. : 738, FMald tests: 78.67, $\mathrm{R}^{2}: 0.416$

The symbols $* * *, * *$, and $*$ represent statistical significance at the $1 \%, 5 \%$, and $10 \%$ level, respectively. 
Meanwhile, most coefficients of our control variables are signed as expected except for the size of banks. Table 7 shows the negative effect of Ln(Assets) on bank stability. Boyd, De Nicolo, and Jalal (2006) point out that competition and bank size are endogenously determined and thus one may need to employ instrumental variable estimations. Without endogeneity corrections, they also report the negative effect of bank size. Tabak, Fazio, and Cajueiro (2012) provide a possible explanation for this result that it is because of the negative relationship between capital ratio and bank size. They argue that the larger a bank is, the more it benefits from competition, while greater capital ratio is advantageous for banks in the less competitive markets.

\section{Additional analysis}

So far, we use market shares calculated based on total assets. In this section, we re-estimate Boone indices using market shares of total loans in that competitive pressure is more intensified in loan markets than deposit markets. We also re-calculate market shares of commercial loans and household loans and see whether our results change.

In Table 8, we alternatively estimate Boone indices using market shares based on total loans and re-examine the relationship between competition and stability in the MSB and commercial bank markets. The $Z$-scores with the ROAs for prior four quarters are used as the dependent variable. The results confirm our previous findings that the relationship between competition and stability varies depending on the types of banks. In Panel A (MSB case), the coefficients on Competition and Inverse of Boone Index are positive and significant, suggesting that, consistent with Table 5 and Table 6 , the competitive pressure enhances the stability of MSBs. Panel B (commercial bank case) reports that commercial banks are less vulnerable in less competitive markets, while the effect of competition is nonlinear. The results are consistent with Table 7. 
Table 8: Effects on competition estimated by market shares of total loans

Panel A. Competition and stability in the MSB industry

\begin{tabular}{|c|c|c|c|c|c|c|c|c|}
\hline \multirow{2}{*}{$\operatorname{Ln}\left(Z_{4}\right)$} & \multicolumn{4}{|c|}{ OLS } & \multicolumn{4}{|c|}{ Fixed Effects } \\
\hline & Coef. & $t$-value & Coef. & t-value & Coef. & t-value & Coef. & t-value \\
\hline Competition & 0.1461 & {$[2.84]^{* * *}$} & & & 0.1421 & {$[2.49]^{* *}$} & & \\
\hline Inverse of Boone Index & & & 0.1120 & {$[3.59]^{* * *}$} & & & 0.1127 & {$[3.65]^{* * *}$} \\
\hline Ln(Assets) & -0.0769 & {$[-3.51]^{* * *}$} & -0.0789 & {$[-3.61]^{* * *}$} & -0.3346 & {$[-2.62]^{* *}$} & -0.3471 & {$[-2.81]^{* * *}$} \\
\hline Profit ratio & 0.0027 & {$[4.11]^{* * *}$} & 0.0026 & {$[3.95]^{* * *}$} & 0.0006 & {$[0.66]$} & 0.0005 & {$[0.58]$} \\
\hline Loan to Deposit & 0.0002 & {$[2.48]^{* *}$} & 0.0002 & {$[2.46]^{* *}$} & 0.0006 & {$[2.21]^{* *}$} & 0.0006 & {$[2.31]^{* *}$} \\
\hline Loan to Deposit ${ }^{2}$ & 0.0000 & {$[-1.16]$} & 0.0000 & {$[-1.09]$} & 0.0000 & {$[-1.83]$} & 0.0000 & {$[-1.89]^{*}$} \\
\hline Commercial to Home loan & 0.0043 & {$[3.08]^{* * *}$} & 0.0043 & {$[3.09]^{* * *}$} & -0.0038 & {$[-1.17]$} & -0.0038 & {$[-1.17]$} \\
\hline$C D$ Volatility & -0.2935 & {$[-4.51]^{* * *}$} & -0.2970 & {$[-4.85]^{* * *}$} & -0.2961 & {$[-4.16]^{* * *}$} & -0.2930 & {$[-4.22]^{* * *}$} \\
\hline Intercept & -0.2260 & {$[-0.52]$} & -0.2219 & {$[-0.51]$} & 0.2526 & {$[0.15]$} & 0.2345 & {$[0.14]$} \\
\hline No. of Obs. & \multicolumn{2}{|c|}{2,164} & \multicolumn{2}{|c|}{2,164} & \multicolumn{2}{|c|}{2,164} & \multicolumn{2}{|c|}{2,164} \\
\hline F/Wald tests & \multicolumn{2}{|c|}{20.10} & \multicolumn{2}{|c|}{20.83} & \multicolumn{2}{|c|}{9.52} & \multicolumn{2}{|c|}{9.98} \\
\hline$R^{2}$ & \multicolumn{2}{|c|}{0.058} & \multicolumn{2}{|c|}{0.063} & \multicolumn{2}{|c|}{0.083} & \multicolumn{2}{|c|}{0.864} \\
\hline
\end{tabular}

Panel B. Competition and stability in the commercial bank industry

\begin{tabular}{|c|c|c|c|c|c|c|c|c|}
\hline \multirow{2}{*}{$\operatorname{Ln}\left(Z_{4}\right)$} & \multicolumn{4}{|c|}{ OLS } & \multicolumn{4}{|c|}{ Random Effects } \\
\hline & Coef. & t-value & Coef. & t-value & Coef. & z-value & Coef. & z-value \\
\hline Competition & -0.5479 & {$[-5.40]^{* * *}$} & & & -0.3068 & {$[-3.00]^{* * *}$} & & \\
\hline Inverse of Boone Index & & & -1.4628 & {$[-5.27]^{* * *}$} & & & -1.1246 & {$[-4.58]^{* * *}$} \\
\hline Inverse of Boone Index ${ }^{2}$ & & & 0.8295 & {$[4.10]^{* * *}$} & & & 0.6944 & {$[3.93]^{* * *}$} \\
\hline Ln(Assets) & -0.1648 & {$[-4.21]^{* * *}$} & -0.1670 & {$[-4.29]^{* * *}$} & 0.5067 & {$[2.79]^{* * *}$} & 0.3463 & {$[3.77]^{* * *}$} \\
\hline Profit ratio & 4.8229 & {$[6.92]^{* * *}$} & 4.9438 & {$[7.04]^{* * *}$} & 4.2733 & {$[5.87]^{* * *}$} & 4.4288 & {$[7.56]^{* * *}$} \\
\hline Foreign & 0.6879 & {$[5.23]^{* * *}$} & 0.6929 & {$[5.29]^{* * *}$} & 0.5316 & [1.53] & 0.5862 & {$[1.54]$} \\
\hline Loan to Deposit & 0.0388 & {$[8.42]^{* * *}$} & 0.0387 & {$[8.33]^{* * *}$} & 0.0349 & {$[2.44]^{* *}$} & 0.0373 & {$[7.68]^{* * *}$} \\
\hline Loan to Deposit ${ }^{2}$ & -0.0001 & {$[-6.88]^{* * *}$} & -0.0001 & {$[-6.77]^{* * *}$} & -0.0001 & {$[-2.22]^{* *}$} & -0.0001 & {$[-6.87]^{* * *}$} \\
\hline Commercial to Home loan & 0.0003 & {$[0.94]$} & 0.0002 & {$[0.83]$} & 0.0007 & [0.89] & 0.0006 & {$[1.47]$} \\
\hline$C D$ Volatility & -0.3547 & {$[-2.86]^{* * *}$} & -0.3380 & {$[-2.74]^{* * *}$} & -0.3409 & {$[-2.18]^{* *}$} & -0.3294 & {$[-3.14]^{* * *}$} \\
\hline Intercept & 3.8635 & {$[6.70]^{* * *}$} & 3.9032 & {$[6.80]^{* * *}$} & -7.6638 & {$[-2.99]^{* * *}$} & -5.0618 & {$[-3.42]^{* * *}$} \\
\hline No. of Obs. & \multicolumn{2}{|c|}{738} & \multicolumn{2}{|c|}{738} & \multicolumn{2}{|c|}{738} & \multicolumn{2}{|c|}{738} \\
\hline $\mathrm{F} /$ Wald tests & \multicolumn{2}{|c|}{30.80} & \multicolumn{2}{|c|}{28.12} & \multicolumn{2}{|c|}{518.10} & \multicolumn{2}{|c|}{287.27} \\
\hline$R^{2}$ & \multicolumn{2}{|c|}{0.234} & \multicolumn{2}{|c|}{0.240} & \multicolumn{2}{|c|}{0.338} & \multicolumn{2}{|c|}{0.326} \\
\hline
\end{tabular}

Notes: Boone index is re-estimated using the market share based on total loans. OLS and panel regressions are estimated for the stability of both MSBs (Panel A) and commercial banks (Panel B). The dependent variable and other description are the same as Table 5 . All tests use robust standard errors and $t / z$-statistics are reported in brackets. The symbols ***, **, and * represent statistical significance at the $1 \%, 5 \%$, and $10 \%$ level, respectively. 
In Table 9, we re-estimate Boone indices using market shares based on commercial loans for MSBs and on household loans for commercial banks. This is why we consider their lending practices. MSBs have concentrated their finance on SMEs (for example, real estate PF loans) while commercial banks have competed fiercely to attract households (for example, home mortgage loans). Notably, this is well shown at the time of real estate boom, from 2005 to 2007 . We then test whether our previous findings are sensitive to the definition of market shares.

Panel A of Table 9 reports the determinants of the stability of MSBs as a function of competition re-estimated by using market shares of commercial loans. In both OLS and panel regressions, the coefficients of Competition and Inverse of Boone Index are still positive and statistically significant, confirming that MSBs tend to be more stable in more competitive markets. In the previous Table 3, Korean MSB industry turns out to have been under the less competitive environment since the recent global financial crisis. As a result, MSBs with greater market share in the loan market imposed higher interest rates on their customers. ${ }^{11)}$ The greater interest rates might increase the risk-taking behavior of borrowing companies. Influenced by this, the risk shifting effect became higher than the interest effect for MSBs. Recently, default risks are enlarged centering on some large-sized MSBs with their larger exposure to existing bad loans.

In Panel B, we examine the commercial bank industry and test the effects of competition based on its market shares of household loans. Again, the Competition dummy is negatively correlated with commercial bank stability. Also, the effects of Boon indices have a negative effect, but the relationship between Boon indices and stability is nonlinear. Overall, our results that the relationship between competition and stability varies depending on the characteristics of banks are robust to a variety of measures of competition and stability as well as model specifications.

11) According to the Bank of Korea (ECOS), average annual lending interest rate of MSBs was $10.9 \%$ from 2005 to 2007 , at the time of higher competition. The rate, however, increased to $13.7 \%$ from 2008 to 2012, when the degree of competition was relatively lower compared to the previous period. On the other hand, domestic commercial banks showed a different lending attitude. Average annual lending interest rate of banks' household loans was 5.9\% on a basis of new loans from 2005 to 2007 and 5.8\% from 2008 to 2012. This fact implies that the risk shifting effect for MSBs is larger than that for commercial banks. 


\section{Table 9: Effects on competition estimated by market shares of commercial or household loans}

Panel A. Competition based on commercial loans and stability of MSBs

\begin{tabular}{|c|c|c|c|c|c|c|c|c|}
\hline \multirow{2}{*}{$\operatorname{Ln}\left(Z_{4}\right)$} & \multicolumn{4}{|c|}{ OLS } & \multicolumn{4}{|c|}{ Fixed Effects } \\
\hline & Coef. & t-value & Coef. & $\mathrm{t}$-value & Coef. & t-value & Coef. & t-value \\
\hline Competition & 0.2122 & {$[4.63]^{* * *}$} & & & 0.2200 & {$[3.75]^{* * *}$} & & \\
\hline Inverse of Boone Index & & & 0.0974 & {$[4.06]^{* * *}$} & & & 0.0975 & {$[3.20]^{* * *}$} \\
\hline $\operatorname{Ln}($ Assets $)$ & -0.0723 & {$[-3.31]^{* * *}$} & -0.0755 & {$[-3.46]^{* * *}$} & -0.2748 & {$[-2.19]^{* *}$} & -0.3083 & {$[-2.43]^{* *}$} \\
\hline Profit ratio & 0.0027 & {$[4.09]^{* * *}$} & 0.0027 & {$[4.18]^{* * *}$} & 0.0006 & {$[0.66]$} & 0.0007 & {$[0.71]$} \\
\hline Loan to Deposit & 0.0002 & {$[2.56]^{* *}$} & 0.0002 & {$[2.45]^{* *}$} & 0.0006 & {$[2.22]^{* *}$} & 0.0006 & {$[2.23]^{*}$} \\
\hline Loan to Deposit ${ }^{2}$ & 0.0000 & {$[-1.29]$} & 0.0000 & {$[-1,13]$} & 0.0000 & {$[-1.87]^{*}$} & 0.0000 & {$[-1.85]$} \\
\hline Commercial to Home loan & 0.0046 & {$[3.31]^{* * *}$} & 0.0045 & {$[3.19]^{* * *}$} & -0.0034 & {$[-1.06]$} & -0.0036 & {$[-1.13]$} \\
\hline$C D$ Volatility & -0.2854 & {$[-4.77]^{* * *}$} & -0.3413 & {$[-6.02]^{* * *}$} & -0.2986 & {$[-4.11]^{* * *}$} & -0.3484 & {$[-4.83]^{* * *}$} \\
\hline Intercept & -0.2881 & {$[-0.66]$} & -0.1637 & {$[-0.38]$} & -0.2078 & {$[-0.12]$} & 0.1397 & {$[0.08]$} \\
\hline No. of Obs. & \multicolumn{2}{|c|}{2164} & \multicolumn{2}{|c|}{2164} & \multicolumn{2}{|c|}{2164} & \multicolumn{2}{|c|}{2164} \\
\hline F/Wald tests & \multicolumn{2}{|c|}{22.13} & \multicolumn{2}{|c|}{21.38} & \multicolumn{2}{|c|}{10.76} & \multicolumn{2}{|c|}{10.03} \\
\hline$R^{2}$ & \multicolumn{2}{|c|}{0.067} & \multicolumn{2}{|c|}{0.062} & \multicolumn{2}{|c|}{0.090} & \multicolumn{2}{|c|}{0.876} \\
\hline
\end{tabular}

Panel B. Competition based on household loans and stability of commercial banks

\begin{tabular}{|c|c|c|c|c|c|c|c|c|}
\hline \multirow{2}{*}{$\operatorname{Ln}\left(Z_{4}\right)$} & \multicolumn{4}{|c|}{ OLS } & \multicolumn{4}{|c|}{ Random Effects } \\
\hline & Coef. & t-value & Coef. & $\mathrm{t}$-value & Coef. & $z$-value & Coef. & $z$-value \\
\hline Competition & -0.5402 & {$[-4.76]^{* * *}$} & & & -0.2509 & {$[-1.86]^{*}$} & & \\
\hline Inverse of Boone Index & & & -1.2158 & {$[-8.42]^{* * *}$} & & & -1.0331 & {$[-8.14]^{* * *}$} \\
\hline Inverse of Boone Index ${ }^{2}$ & & & 0.4295 & {$[8.94]^{* * *}$} & & & 0.3784 & {$[9.60]^{* * *}$} \\
\hline $\operatorname{Ln}($ Assets $)$ & -0.1617 & {$[-4.11]^{* * *}$} & -0.1618 & {$[-4.25]^{* * *}$} & 0.6043 & {$[3.13]^{* * *}$} & 0.1956 & {$[1.29]$} \\
\hline Profit ratio & 4.9084 & {$[7.01]^{* * *}$} & 3.7364 & {$[5.37]^{* * *}$} & 4.2732 & {$[6.06]^{* * *}$} & 3.3183 & {$[4.34]^{* * *}$} \\
\hline Foreign & 0.6918 & {$[5.16]^{* * *}$} & 0.6694 & {$[5.34]^{* * *}$} & 0.5124 & {$[1.37]$} & 0.6069 & {$[2.29]^{* *}$} \\
\hline Loan to Deposit & 0.0396 & {$[8.42]^{* * *}$} & 0.0349 & {$[7.61]^{* * *}$} & 0.0347 & {$[2.39]^{* *}$} & 0.0350 & {$[2.40]^{* *}$} \\
\hline Loan to Deposit ${ }^{2}$ & -0.0001 & {$[-6.79]^{* * *}$} & -0.0001 & {$[-5.80]^{* * *}$} & -0.0001 & {$[-2.19]^{* *}$} & -0.0001 & {$[-2.01]^{* *}$} \\
\hline Commercial to Home loan & 0.0003 & {$[0.94]$} & 0.0000 & {$[0.06]$} & 0.0007 & {$[0.96]$} & 0.0004 & {$[0.56]$} \\
\hline$C D$ Volatility & -0.1936 & {$[-1.59]$} & -0.0552 & {$[-0.48]$} & -0.2527 & {$[-1.67]^{*}$} & -0.1115 & {$[-0.70]$} \\
\hline Intercept & 3.7491 & {$[6.54]^{* * *}$} & 3.9344 & {$[7.14]^{* * *}$} & -9.3874 & {$[-3.39]^{* * *}$} & -2.3821 & {$[-1,17]$} \\
\hline No. of Obs. & \multicolumn{2}{|r|}{738} & \multicolumn{2}{|c|}{738} & \multicolumn{2}{|c|}{738} & \multicolumn{2}{|c|}{738} \\
\hline F/Wald tests & \multicolumn{2}{|c|}{29.59} & \multicolumn{2}{|c|}{34.38} & \multicolumn{2}{|c|}{419.01} & \multicolumn{2}{|c|}{1069.54} \\
\hline$R^{2}$ & \multicolumn{2}{|c|}{0.233} & \multicolumn{2}{|c|}{0.277} & \multicolumn{2}{|c|}{0.347} & \multicolumn{2}{|c|}{0.354} \\
\hline
\end{tabular}

Notes: Boone index is re-estimated using the market share based on commercial loans for MSBs and on household loans for commercial banks. OLS and panel regressions are estimated for the stability of both MSBs (Panel A) and commercial banks (Panel B). The dependent variable and other description are the same as Table 5 . All tests use robust standard errors and $t / z$-statistics are reported in brackets. The symbols $* * *, * *$, and * represent statistical significance at the $1 \%, 5 \%$, and $10 \%$ level, respectively. 


\section{Conclusion}

There are two alternative hypotheses that relate bank competition to stability. The conventional competition-fragility theory suggests that the higher competition in financial industry causes financial institutions to lose their market powers, leading to a decrease in their profitability. In order to recover from those financial losses, individual financial institutions are more likely to invest in riskier portfolios. Consequently, this risk-taking behavior will undermine financial institutions' stability. One the other hand, competition-stability theory suggests that competition has a potentially positive effect on the stability of financial institutions. Accordingly, Boyd and De Nicolo (2005) show that banks with greater market share in the loan market which experience lower competition tend to impose higher interest rates on their loans. The greater interest rate charged by banks in a less competitive market may increase the risk-taking behavior of borrowing firms. Boyd and De Nicolo consequently argue that since the risk is ultimately shifted from borrowers to banks, the default probability of banks gradually goes up in the riskiness of bank loans.

The recent study by Martinez-Miera and Repullo (2010) support, in part, Boyd and De Nicolo (2005)'s risk-shifting effect that greater interest rates in less competitive markets raise the risk of loans and thus make a bank bankruptcy more likely. They, however, additionally take into account the fact that greater interest rates also improve bank profitability, called the interest effect or margin effect, which is not considered in Boyd and De Nicolo. They suggest the U-shaped relationship between competition and the risk of bank failure. So far, empirical research has produced mixed results on the influence of bank competition on its stability.

The purpose of this paper is to investigate the relationship between competition and stability by using the sample of two different types of Korean banks: MSBs and commercial banks. By doing so, we attempt to fill the gap in literature by examining whether differences in terms of governance structure, business models and regulatory treatments cause banks to interact with industry competition differently. It is generally known that the governance structure of MSBs is not transparent and their customers are mainly made up of borrowers with weaker debt servicing capacity than those of commercial banks. Also, the regulation for MSBs has not been relatively tightened compared to commercial banks.

We use quarterly panel data of MSBs and commercial banks from 1999, the end of 
Asian financial crisis, through 2011. We follow Boone (2008) which measures competitiveness using operating efficiency, known as the Boone index. This non-structural approach measures bank competition without considering the type of market structure or the number of banks. Since the number of MSBs and commercial banks continue to be a downward trend, this paper mainly selects the competition-contestability theory which measures competition irrespective of the number of banks, instead of the SCP assumption. Of course, the conventional concentration ratio and Herfindahl-Hirschman Index are used as well as supplementary measures for bank competition. In particular, this concentration degree is very meaningful to MSBs in Korea because market shares have been concentrated on some large-sized MSBs in a less competitive loan market as long as their default risks have been mounting since the recent global financial crisis. We employ the $Z-$ score as a measure of bank stability which can capture how distant a certain bank is from its insolvency. Finally, we perform pooling regressions as well as panel analyses to examine the relationship between competitive levels and stability of MSBs and commercial banks. Section III describes our measures and methodology in more details.

Our estimated Boone indices, indicative of competitiveness within the relevant financial sector, suggest that competition pressure in fact exists in both the commercial bank and MSB industry during our total sample period. According to the quarterly Boone indices, competition turns out to have been much higher before the recent global financial crisis, but after then it has gradually declined in commercial banks as well as MSBs.

In addition to this, our empirical results generally support the hypothesis that the effect of bank competition on stability is different depending on the characteristics of banks. This is similar to the study of Liu and Wilson (2011). They also find that competition enhances the stability of banks with lower stability levels, but has a negative impact on the stability of banks with higher stability levels in the Japanese banking market.

As Boyd and De Nicolo (2005) suggest, the results of our multiple regressions for MSBs show that competition has a significant and positive effect on the stability of MSBs with weak corporate governance. MSBs with greater market shares tend to impose higher interest rates on their loans. This may increase the debt servicing burdens of borrowers and their risk-taking behaviors to make repayment funds. Ultimately, the default risk is shifted from borrowers to MSBs. Additionally, higher concentration risks 
may lead to undermine the stability of MSBs in a less competitive loan market due to the rising default problems of their non-performing loan (NPL). In essence, MSBs are more likely to face defaults in the event of downturn in the real estate market and real economy. It is why they hold more low-rated and vulnerable borrowers. On the contrary, competition pressure significantly reduces the stability of commercial banks but, consistent with Tabak, Fazio, and Cajueiro (2012), the relationship turns out to be nonlinear. The results are robust across alternative proxies for competition and stability as well as various model specifications. Therefore, we conclude that for commercial banks higher competition creates the trade-off between the risk-shifting effect and interest effect, but the risk shifting effect overwhelms the interest effect for MSBs when their market is less competitive.

This paper contributes in the several ways. The aim of our research is to provide comprehensive evidence on the relationship between bank competition and stability, conditional on different bank characteristics. Our findings contribute to a more comprehensive understanding of the effect of competitive environment in the bank industry. Also, it is the first paper to analyze the relationship between competition and stability of MSBs by using hand-collected data. So far, there is no published empirical research examining MSBs due to lack of available data because most MSBs are non-listed. Finally, the use of quarterly data instead of annual data provides more reliable results from our empirical tests with a larger number of observations. 


\section{References}

Allen, F., and D. Gale (2000), "Comparing Financial Systems," MIT Press.

Baumol, W. J. (1982), "Contestable Markets: An Uprising in the Theory of Industry Structure," American Economic Review, Vol. 72, pp. 1-15.

Baumol, W. J., Panzar, J. C., and R. D. Willig (1982), "Contestable Markets and the Theory of Industry Structure,” New York: Harcourt Brace Jovanovich.

Beck, T., Jonghe, O. D., and G. Schepens (2012), "Bank Competition and Stability: Cross-country Heterogeneity," Journal of Financial Intermediation, forthcoming.

Berger, A. N., Klapper, L. F., and R. Turk-Ariss (2009), "Bank Competition and Financial Stability," Journal of Financial Service Research, Vol. 35, pp. 99-118.

Bikker, J. A., and K. Haaf (2002), "Competition, Concentration and their Relationship: An Empirical Analysis of the Banking Industry," Journal of Banking \& Finance, Issue 11, Vol. 26, pp. 2191-2214.

Bikker, J. A., Shaffer, S., and L. Spierdijk (2012), "Assessing Competition with the Panzar-Rosse Model: the Role of Scale, Costs, and Equilibrium," Review of Economics and Statistics, Issue 4, Vol. 94, pp. 1025-1044.

Boone, J. (2008), "A New Way to Measure Competition," Economic Journal, Vol. 118, pp. 1245-1261.

Boone, J. (2008), "Competition: Theoretical Parameterization and Empirical Measure," Journal of Institutional and Theoretical Economics, Vol. 164, pp. 587-611.

Boyd, J. H., and G. D. Nicolo (2005), "The Theory of Bank Risk Taking and Competition Revisited," Journal of Finance, Vol. 60, No. 3, pp. 1329-1343.

Boyd, J. H., G. D. Nicolo, and A. M. Jalal (2006), "Bank Risk Taking and Competition Revisited: New Theory and Evidence," IMF Working papers, No. $06 / 297$.

Bulow, J., and P. Klemperer (2002), "Prices and the Winner's Curse," Rand Journal of Economics, Vol. 33, No. 1, pp. 1-21. 
Hellmann, T. F., Murdock, K. C., and J. E. Stiglitz (2000), "Liberalization, Moral Hazard in Banking, and Prudential Regulation: Are Capital Requirements Enough?” American Economic Review, Issue. 1, Vol. 90, pp. 147-165.

Jeong, H. K., and J. G. Kang (2006), "The Influence that An Increase in Concentration and Competition within Korean Banking Industry has on Efficiency of Banks," financial and economic working papers of the Bank of Korea, No. 274. pp. 1-28.

Jeong, H. K., and S. W. Joh (2009), "The Effects that Concentration in Korean Banking Industry has on Risk-taking Attitude and Efficiency of Banks," financial research reports of Korea Institute of Finance, No. 2009-3, pp. 1-30.

Keeley, M. C. (1990), "Deposit Insurance, Risk, and Market Power in Banking," American Economic Review, Vol. 80, No. 5, pp. 1183-1200.

Leuvensteijn, M. V., Bikker, J. A., Rixtel, A. V., C. K. Sorensen (2011), "A New Approach to Measuring Competition in the Loan Markets of the Euro Area," Applied Economics, Issue 23, Vol. 43, pp. 3155-3167.

Liu, H., and J. O. S. Wilson (2011), "Bank Type, Competition and Stability in Japanese Banking," University of St. Andrews Working papers.

Martinez-Miera, D., and R. Repullo (2010), “Does Competition Reduce the Risk of Bank Failure?” Review of Financial Studies, Vol. 23, No. 10, pp. 3638-3664.

Mercieca, S., Schaeck, K., and S. Wolfe (2007), "Small European Banks: Benefits from Diversification?” Journal of Banking \& Finance, Issue 7, Vol. 31, pp. 1975-1998.

Panzar, J. C., and J. N. Rosse (1987), "Testing for "Monopoly" Equilibrium," Journal of Industrial Economics, Vol. 35, No. 4, pp. 443-456.

Roy, A. D. (1952), "Safety First and the Holding of Assets," Econometrica, Vol. 20, No. 3, pp. 431-449.

Schaeck, K., and M. Cihak (2010), "Banking Competition and Capital Ratios," European Financial Management, Issue 5, Vol. 18, pp. 836-866.

Stiglitz, J. E. (1989), "Imperfect Information in the Product Market," Handbook of industrial organization, Vol. 1, No. 1, pp. 769-847. 
Tabak, B. M., Fazio, D. M., and D. O. Cajueiro (2012), "The Relationship between Banking Market Competition and Risk-taking: Do Size and Capitalization Matter?" Journal of Banking \& Finance, Vol. 36, No. 12, pp. 3366-3381.

The Bank of Korea (2008), "The Assessment of Competition in Banking Industry," BOK press release. 


\section{$<$ Abstract in Korean $>$}

\section{전진규*, 임광규**}

본 연구는 외환위기 이후 우리나라 금융산업에 존재하는 경쟁도를 측정하는 한편 경쟁 도 변화가 금융안정에 미치는 영향을 은행과 저축은행을 중심으로 비교·분석하였다. 기 존 문헌연구에 따르면, 경쟁도와 안정성간의 관계에 대해 두 가지의 상반된 가설이 존재한 다. 경쟁도가 높아질수록 개별 금융기관들의 위험추구행위(risk-taking behavior)가 확대 되어 금융산업의 안정성이 저해되는 것으로 이해하는 전통적인 이론(competition-fragility hypothesis)과 경쟁도가 낮고 집중도가 높아질수록 위험전이효과(risk-shifting effect)로 인해 금융기관의 경영안정성이 취약해질 수 있다는 이론(competition-stability hypothesis)이다.

이러한 관점에서 본 연구에서는 우리나라 금융산업에서 대체로 서로 다른 영업행태와 지배구조를 갖는 은행과 저축은행을 대상으로 분기별 패널데이타를 이용하여 이를 실증 분석해 보았다. 경쟁도 측정 모형으로는 산업구조(금융기관 수 등)와 상관없이 개별 금융 기관의 경영행태를 기반으로 측정되는 Boone Index를, 금융안정 변수로는 $Z-s c o r e$ 를 이용하였다.

분석 결과, 은행과 저축은행 산업 모두 대체로 글로벌 금융위기 이전에는 경쟁도가 높 았으나 위기 이후에는 점차 축소되고 있는 것으로 파악되었다. 그러나 경쟁도가 금융안정 에 미치는 영향은 금융산업의 특징별로 상이하게 나타났다. 먼저 저축은행의 경우 Boyd and De Nicolo (2005)가 주장한 것처럼 경쟁도 하락이 금융기관의 경영안정성에 부정적 인 영향을 주는 것으로 분석되었다. 이는 저축은행 차입자의 경우 대부분 높은 대출금리 를 부담함에도 상환능력은 취약한 저신용 차주여서 경쟁도가 하락(집중도가 상승)하면 위험전이효과가 커지기 때문인 것으로 여겨진다. 특히 거래상대방 위험이 분산되지 못한 채 취약대출이 많은 일부 저축은행으로 편중되면서 해당 산업내 불안정성이 증대될 수 있다. 반면, 차주 구성이 우량 차주로 되어 있는 은행의 경우 산업내 경쟁도가 높아질수록 수익성 저하에 따른 위험선호행위가 증가하므로 경쟁도 상승이 은행산업의 안정성을 감 소시키는 것으로 판단된다. 다만 그 영향은 비선형적으로 체감하는 것으로 나타났다.

* 동국대학교 경영전문대학원 재무학 교수

** 한국은행 거시건전성분석국 조기경보팀 과장

연구내용은 집필자의 개인의견이며 한국은행의 공식견해와는 무관합니다. 따라서 본 논문의 내용을 보도하 거나 인용할 경우에는 집필자명을 반드시 명시하여 주시기 바랍니다. 
